\title{
Crimes, Widgets, and Plea Bargaining: An Analysis of Charge Content, Pleas, and Trials
}

\author{
Kyle Graham*
}

This Article considers how the composition and gravamen of a charged crime can affect the willingness and ability of the prosecution and defense to engage in plea bargaining. Most of the prevailing descriptions of plea bargaining ignore or discount the importance of charge content in plea negotiations; in fact, one leading commentator has likened crimes to widgets insofar as plea bargaining is concerned. In developing its counterthesis, this Article reviews seven years (FY2003-FY2009) of federal conviction data, focusing on those crimes that produce the most, and fewest, trials, relative to how often they are alleged; the most, and fewest, acquittals at trial; and the most, and fewest, plea bargains that involve a substantial alteration in charges. Overall, the data demonstrate that the character of, and circumstances that surround, a particular offense can catalyze or frustrate plea bargaining. Similar information to that gleaned from this study can and should be considered in connection with the adoption of new crimes and the reevaluation of existing offenses. This information would provide legislatures with insight into how a proposed crime is likely to be utilized and how current crimes are being used in plea bargaining.

Introduction.

I. The Market Model of Plea Bargaining

II. Crime Characteristics and Plea Bargaining. 1584

A. Incomplete or Imperfect Information

Copyright (C) 2012 California Law Review, Inc. California Law Review, Inc. (CLR) is a California nonprofit corporation. CLR and the authors are solely responsible for the content of their publications.

* Assistant Professor, Santa Clara University School of Law. The author would like to thank David Ball, Stephanos Bibas, David Friedman, Eric Goldman, Pratheepan Gulasekaram, Brad Joondeph, Ellen Kreitzberg, Angela Machala, David Sklansky, David Sloss, and Ronald Wright for their helpful comments. 
1. Ease or Difficulty of Proof...................................................... 1586

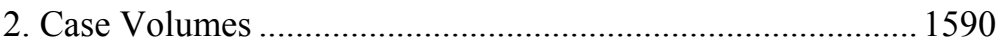

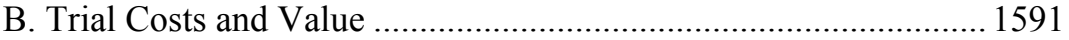

C. Limited and Expansive Compromise Options ............................. 1594

III. Federal Data on Plea Bargaining and Trials ……….............................. 1598

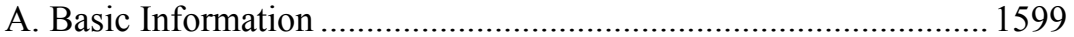

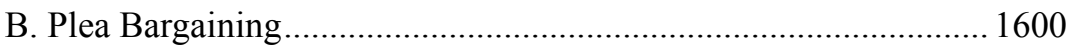

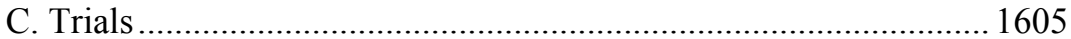

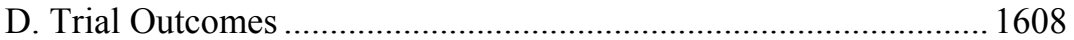

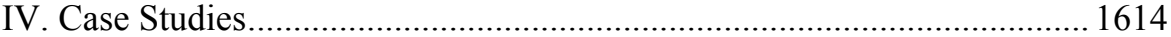

A. 18 U.S.C. $\S 242$ (Deprivation of Civil Rights Under Color of

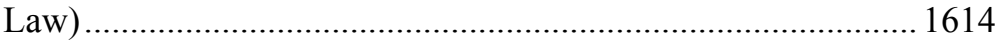

B. 8 U.S.C. $\S 1326$ (Reentry of a Deported Alien)............................ 1617

C. 18 U.S.C. $\S 924(j)$ (Use of a Firearm in the Commission of a

Federal Felony, Resulting in Death) ........................................... 1619

D. 21 U.S.C. $\S 952$ (Importation of Marijuana) .................................. 1622

E. 26 U.S.C. § 7201 (Tax Evasion) ……………………………..... 1625

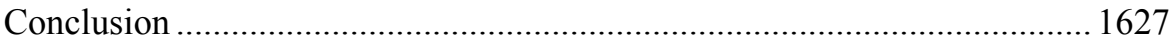

\section{INTRODUCTION}

More so than most federal crimes, felony tax evasion, codified at 26 U.S.C. $\S 7201,{ }^{1}$ tends to produce convictions when taken to trial. According to data compiled by the Administrative Office of the United States Courts (AOUSC), ${ }^{2}$ less than 14 percent of all tried counts that allege this crime result

1. Any person who willfully attempts in any manner to evade or defeat any tax imposed by this title or the payment thereof shall, in addition to other penalties provided by law, be guilty of a felony and, upon conviction thereof, shall be fined not more than $\$ 100,000$ $(\$ 500,000$ in the case of a corporation), or imprisoned not more than 5 years, or both, together with the costs of prosecution.

26 U.S.C. $\S 7201$ (2006).

2. The data referenced in the text above derive from a series of datasets that each contain information regarding federal criminal cases that terminated in a given fiscal year (October 1 to September 30), which the author has compiled into a single database [hereinafter the "AOUSC Database"], which remains in the possession of the author. The datasets comprising this database are as follows: United States Department of Justice; Bureau of Justice Statistics; Federal Justice Statistics Program: Defendants in Federal Criminal Cases in District Court-Terminated, 2003 [ICPSR 24153]; United States Department of Justice, Bureau of Justice Statistics, Federal Justice Statistics Program: Defendants in Federal Criminal Cases in District Court-Terminated, 2004 [ICPSR 24170]; United States Department of Justice, Bureau of Justice Statistics, Federal Justice Statistics Program: Defendants in Federal Criminal Cases in District Court-Terminated, 2005 [ICPSR 24187]; United States Department of Justice, Bureau of Justice Statistics, Federal Justice Statistics Program: Defendants in Federal Criminal Cases in District Court-Terminated, 2006 [ICPSR 24205]; United States Department of Justice, Bureau of Justice Statistics, Federal Justice Statistics Program: Defendants in Federal Criminal Cases in District Court-Terminated, 2007 [ICPSR 24222]; United States Department of Justice, Bureau of Justice Statistics, Federal Justice Statistics Program: Defendants in Federal Criminal Cases in District Court-Terminated, 2008 [ICPSR 29242]; and United States Department of Justice, Bureau of Justice Statistics, Federal Justice Statistics Program: Defendants in Federal Criminal Cases in District Court-Terminated, 2009 [ICPSR 30784]. 
in not-guilty verdicts. ${ }^{3}$ This figure is significantly lower than the overall acquittal rate at trial across federal crimes. ${ }^{4}$ Given the slim prospects for acquittal, one would expect that defendants charged with this offense would agree to pretrial guilty pleas relatively often. By doing so, these defendants would position themselves to receive a sentence reduction for their early acceptance of responsibility - as good an outcome as they might expect under the circumstances. ${ }^{5}$ In fact, the contrary is true-this charge is approximately three times more likely to be taken to trial than the "average" crime is. ${ }^{6}$

At the other extreme, deprivation of civil rights under the color of law, codified at 18 U.S.C. $\S 242,^{7}$ may be the most difficult crime for federal prosecutors to prove at trial. Per AOUSC data, juries return not-guilty verdicts on about half of all tried counts that allege this offense. ${ }^{8}$ Does this acquittal rate lead to a relatively high number of trials? Or does the prosecutor's willingness

3. AOUSC Database, supra note 2.

4. The overall acquittal rate, on a count-by-count basis, is approximately 21 percent. See infra text accompanying notes $144-47$.

5. Pursuant to the Federal Sentencing Guidelines, a federal criminal defendant who "clearly demonstrates acceptance of responsibility for his offense" is eligible for a two-level sentence reduction. U.S. SENTENCING GUIDELINES MANUAL § 3E1.1 (2011). Furthermore, if a defendant qualifies for this reduction, the base offense level associated with the offense is 16 or greater, and the government files a motion stating that the defendant has assisted authorities in the investigation or prosecution of her own misconduct by timely notifying authorities of her intention to enter a plea of guilty, thereby permitting the government to avoid preparing for trial and permitting the government and the court to allocate their resources efficiently, the base offense level will be decreased by one additional level. Id. "[T] he timeliness of the defendant's conduct in manifesting the acceptance of responsibility" is among the factors considered in determining whether a defendant has clearly accepted this responsibility. Id. at cmt. n.1(H). A large percentage of defendants who enter guilty pleas receive the benefit of this reduction. U.S. SENTENCING COMMISSION, 2010 SOURCEBOOK OF FEDERAL SENTENCING STATISTICS, tbl.18 (2011), available at http://www.ussc.gov/Data_and_Statistics/ Annual_Reports_and_Sourcebooks/2010/Table18.pdf (reflecting that 94.9 percent of all defendants with reported conviction dispositions in fiscal year 2010 received the benefit of the two- or three-level acceptance of responsibility reduction); Ronald F. Wright, Trial Distortion and the End of Innocence in Federal Criminal Justice, 154 U. PA. L. REV. 79, 131 (2005) (discussing comparable figures from earlier in the 2000s).

6. See infra text accompanying note 274 .

7. The statute provides as follows:

Whoever, under color of any law, statute, ordinance, regulation, or custom, willfully subjects any person in any State, Territory, Commonwealth, Possession, or District to the deprivation of any rights, privileges, or immunities secured or protected by the Constitution or laws of the United States, or to different punishments, pains, or penalties, on account of such person being an alien, or by reason of his color, or race, than are prescribed for the punishment of citizens, shall be fined under this title or imprisoned not more than one year, or both; and if bodily injury results from the acts committed in violation of this section or if such acts include the use, attempted use, or threatened use of a dangerous weapon, explosives, or fire, shall be fined under this title or imprisoned not more than ten years, or both; and if death results from the acts committed in violation of this section or if such acts include kidnapping or an attempt to kidnap, aggravated sexual abuse, or an attempt to commit aggravated sexual abuse, or an attempt to kill, shall be fined under this title, or imprisoned for any term of years or for life, or both, or may be sentenced to death.

18 U.S.C. $§ 242$ (2006).

8. See infra text accompanying note 189 . 
to cut a deal in these cases more than offset the defendant's eagerness to go before a jury, facilitating guilty pleas? ${ }^{9}$ Existing scholarship does not provide definitive answers to these questions. As it turns out, 18 U.S.C. $\S 242$ is one of the most commonly tried crimes, relative to the number of cases in which it is alleged..$^{10}$

The plea bargaining and trial practice that surrounds crimes like tax evasion and deprivation of civil rights suggests that the ongoing conversation over why and how parties engage in plea bargaining has overlooked an important consideration. To date, explanations of the plea-bargaining process have focused on (1) the thought processes and priorities of the relevant actors; ${ }^{11}$ (2) institutional rules, policies, and practices that constrain or encourage plea bargaining; or (3) the organization and structure of the criminal codes that provide the backdrops to these bargains. The first approach either treats defendants, their attorneys, and prosecutors as bargaining "in the shadow of trial, $" 12$ or considers how the circumstances of and pressures on these actors lead to bargains that do not reflect likely trial outcomes. ${ }^{13}$ The second addresses matters such as the discretion judges are allowed to exercise at sentencing, ${ }^{14}$ the pressure to negotiate associated with high case volumes, ${ }^{15}$ the policies that

9. See Albert W. Alschuler, The Prosecutor's Role in Plea Bargaining, 36 U. CHI. L. REV. 50, 59-61 (1968) (asserting that prosecutors have stronger incentives to engage in plea bargaining when their cases are relatively weak); Richard Birke, Reconciling Loss Aversion and Guilty Pleas, 1999 UTAH L. REV. 205, 220 ("A prosecutor who cared to produce a plea would have to reduce charges significantly if the prosecutor had a weak evidentiary case."); Dean J. Champion, Private Counsels and Public Defenders: A Look at Weak Cases, Prior Records, and Leniency in Plea Bargaining, 17 J. CRIM. JUST. 253, 257 (1989). But cf. HARRY KALVEN JR. \& HANS ZEISEL, THE AMERICAN JURY 30-31 (1986) (surmising that the strongest cases are the most likely to produce guilty pleas).

10. See infra text accompanying note 175 .

11. Ronald Wright has described this approach as being concerned with the "micro-level intentions" of the parties. Wright, supra note 5, at 92.

12. This phrase originated in Robert H. Mnookin \& Lewis Kornhauser, Bargaining in the Shadow of the Law: The Case of Divorce, 88 YALE L.J. 950 (1979).

13. E.g., Albert W. Alschuler, The Defense Attorney's Role in Plea Bargaining, 84 YALE L.J. 1179, 1203-06, 1313 (1975) (discussing the incentives that may lead defense attorneys to recommend guilty pleas that are not in their clients' interests); Stephanos Bibas, Plea Bargaining Outside the Shadow of Trial, 117 HARV. L. REV. 2463 (2004).

14. E.g., GeOrge Fisher, Plea BARgaining's TRIUMPH: A History OF PlEA BARgaining IN AMERICA 221-27 (2003) (discussing the effects that the Federal Sentencing Guidelines have had on plea bargaining).

15. E.g., Milton Heumann, A Note on Plea Bargaining and Case Pressure, 9 LAW \& SOC'Y REV. 515, 516 (1975) ("Much of the informed thought and literature on plea bargaining assumes (or at least conveys the impression) that plea bargaining can be best (though not necessarily exclusively) understood as a function of case pressure."); Peter F. Nardulli, The Caseload Controversy and the Study of Criminal Courts, 70 J. CRIM. L. \& CRIMINOLOGY 89, 89-90 (1979) (discussing the perception that the pressures associated with large caseloads account for plea bargaining); William J. Stuntz, Plea Bargaining and Criminal Law's Disappearing Shadow, 117 HARV. L. REV. 2548, 2554 56 (2004) (discussing the importance of docket pressure in giving prosecutors an incentive to plea bargain). 
particular prosecutorial authorities adopt with regard to plea bargaining, ${ }^{16}$ and informal courtroom customs. ${ }^{17}$ The third concentrates on the presence of overlapping offenses within a criminal code, which can give a prosecutor more tools for coercing plea bargains, ${ }^{18}$ and the "space"-in terms of probable sentencing consequences - that exists between related crimes within a code, which may affect the likelihood of a guilty plea to a given charge. ${ }^{19}$

None of these approaches focuses on the quiddities of particular crimes, and the effect that these idiosyncrasies may have on the plea-bargaining process. $^{20}$ This gap, though significant, is understandable. There can be several hundred $^{21}$ or even thousands ${ }^{22}$ of crimes in a single jurisdiction's criminal code, and charging, plea-bargaining, and trial data for specific offenses can be difficult to obtain and exploit. ${ }^{23}$ Difficult, but not impossible. The federal government, for example, collects charge-level data for all criminal cases filed and terminated in United States district court. The amount of data involved is massive-the most recent seven years of released information (which concern cases terminated in federal district court between October 2002 and September 2009) relates the disposition of more than 1.2 million criminal counts. But when harnessed, the data provide significant insight into parties' decisions to engage in plea bargaining, or to take cases to trial.

Above all else, the data reveal that substance matters. The content and character of a charged offense-its essential elements, the proof required to establish the offense, and the basic gravamen of the crime-can make a

16. E.g., Ronald Wright \& Marc Miller, The Screening/Bargaining Tradeoff, 55 StAN. L. REV. 29 (2002).

17. E.g., JAMES Eisenstein \& HERBERT JACOB, Felony Justice: AN ORgANiZATIONAL ANALYSIS OF CRIMINAL COURTS 246-52 (1977) (discussing how stable courtroom workgroups facilitate plea bargaining); Stephen J. Schulhofer \& Ilene H. Nagel, Plea Negotiations Under the Federal Sentencing Guidelines: Guideline Circumvention and Its Dynamics in the Post-Mistretta Period, 91 Nw. U. L. REV. 1284, 1294-96 (1997).

18. E.g., William J. Stuntz, The Pathological Politics of Criminal Law, 100 MiCH. L. ReV. 505, 531 (2001) (discussing the creation of overlapping crimes).

19. E.g., Ronald F. Wright \& Rodney L. Engen, Charge Movement and Theories of Prosecutors, 91 MARQ. L. REV. 9 (2007); Ronald F. Wright \& Rodney L. Engen, The Effects of Depth and Distance in a Criminal Code on Charging, Sentencing, and Prosecutor Power, 84 N.C. L. REV. 1935, 1940 (2006).

20. As far back as 1927, one the first academics to focus on plea bargaining wrote that existing surveys "have not always given us sufficient detail as to the types of cases in which compromises have been most frequent." Justin Miller, The Compromise of Criminal Cases, 1 S. CAL. L. REV. 1, 12 (1927). Miller's article did go on to relate certain classes of crimes in which plea bargaining was most frequent, however. See id. at 12-16 (identifying desertion, violations of the liquor laws, automobile theft, seduction, and statutory rape as among the crimes most likely to be "compromised").

21. Stuntz, supra note 18, at 514 (counting the number of crimes recognized within Illinois, Virginia, and Massachusetts state law).

22. See John S. Baker Jr., Revisiting the Explosive Growth of Federal Crimes, 26 LEGAL MEMORANDUM, June 16, 2008, at 1 (estimating that there exist 4450 federal crimes, as of 2007).

23. See Josh Bowers, Legal Guilt, Normative Innocence, and the Equitable Decision Not to Prosecute, 110 COLUM. L. REV. 1655, 1715 (2010) (discussing the difficulties associated with locating data on misdemeanor case processing). 
considerable difference in the frequency and composition of plea bargains in cases alleging the offense. Crimes vary in several respects material to plea bargaining. These differences include, but are not limited to: the ease or difficulty of proving a charge at trial; the number of prosecutions for the offense; whether the defense, prosecution, or both are likely to ascribe significant value to taking the charge to trial; and the availability and attractiveness of plea-bargaining options. The relationships between these variables and the plea-bargaining practices that surround a particular crime can be difficult to discern. This effort, however, ultimately leads to a more accurate, if more complicated, understanding of plea bargaining than that produced by existing scholarship.

In particular, consideration of charge substance both fleshes out and reveals the limitations of the conventional rational-actor model of the pleabargaining process. This model perceives plea bargaining as a sort of market transaction, and treats crimes with comparable sentencing consequences as essentially fungible. Bringing the point home, the jurist most closely associated with the market analogy, Judge Frank Easterbrook, has likened crimes to widgets insofar as plea bargaining is concerned. ${ }^{24}$ The actual utilization of offenses such as 26 U.S.C. $\S 7201$ and 18 U.S.C. $\S 242$ establishes that, with apologies to Judge Easterbrook, crimes are not widgets. Rather, the composition and connotations of a crime-not just the likely sentence that will adhere in a particular case-can have a significant bearing on plea bargaining, such that two crimes that involve roughly similar custodial terms may produce quite different pleading practices and trial rates.

In detailing the importance of charge substance to plea bargaining, this Article complements other critical assessments of the rational-actor model. Specifically, the content and character of a particular offense can determine the relative costs and benefits of trials and guilty pleas, affect a defendant's or prosecutor's ability to accurately predict case outcomes, and combine with code structure to facilitate or frustrate plea bargaining. In other words, charge substance affects not only the contours of the "shadow of trial," but also the ability of the parties to perceive these likely outcomes and the extent to which this information will cause them to choose plea bargains over trials. Ultimately, this Article builds a case against applying generalizations about plea-bargaining practice to all crimes, or across broad categories of crimes. One must closely consider the precise content and meaning of a charged offense, together with other material influences, to obtain an accurate picture of the plea bargaining that will occur in cases charging that particular crime.

This Article also contains a normative component. I argue that it is not only interesting, but important, to consider how charge substance affects plea

24. Frank H. Easterbrook, Criminal Procedure as a Market System, 12 J. LEGAL STUD. 289, 308 (1983). 
bargaining and trial rates and outcomes. While bargaining practices are highly crime specific, they are not entirely incapable of prediction. If one can anticipate how the parties in future criminal cases will utilize a crime that is under legislative consideration, this knowledge may lead to a more thoughtful and well-developed assessment of the proposed offense's value. For instance, if one can foresee that a new crime will lead to a high number of trials, relative to how often it will be charged, the costs of those trials can and should be incorporated into the legislature's decision whether to enact the crime. Similarly, if a proposed crime resembles existing offenses that parties frequently plead down to lesser crimes, this fact also should become part of the legislative calculus.

The discussion below proceeds as follows. Part I summarizes prevailing explanations of why, and how, parties and their agents engage in plea bargaining. Part II considers the various ways in which the content of specific crimes may catalyze or chill plea bargaining. Part III examines seven years of data, reflecting the disposition of all criminal cases terminated in federal district court between October 2002 and September 2009. The charge-level data from these cases reveal substantial variation in trial and plea-bargaining rates across crimes. To shed light on these differences, Part IV more closely considers the plea-bargaining and trial data for a few specific crimes, including 26 U.S.C $\S 7201$ and 18 U.S.C. $\S 242$. Finally, Part V offers some concluding thoughts about how the consideration of crime-specific data may improve the evaluation of proposed and existing crimes.

I.

\section{The MARKET MOdel OF PleA BARGAINING}

Over the past quarter-century, much of the debate over plea bargaining has revolved around whether, and to what extent, the plea-bargaining process can be explained and justified by analogizing it to an everyday market transaction.

Today, the market analogy is most closely associated with Judge Frank Easterbrook. ${ }^{25}$ In his 1983 article, Criminal Procedure as a Market System, Easterbrook argued that plea bargaining, together with other accoutrements of criminal procedure, could "be understood as elements of a well-functioning market system" that "set the "price' of crime" 26 and thereby tend to "get the maximum deterrent punch out of whatever resources are committed to crime control."27 Describing plea negotiations, Easterbrook asserted that a

25. Easterbrook was not the first commentator to analogize plea bargaining to a market transaction, see, e.g., Richard P. Adelstein, The Negotiated Guilty Plea: A Framework for Analysis, 53 N.Y.U. L. REV. 783, 809 (1978); H. Richard Uviller, Pleading Guilty: A Critique of Four Models, 41 LAW \& CONTEMP. PROBS. 102, 102-03 (1977), but he expanded upon existing analysis.

26. Easterbrook, supra note 24 , at 289.

27. Id. at 290 . 
"prosecutor will have a minimum settlement demand determined by the penalty the prosecutor thinks he may obtain after trial and the cost of holding the trial (less the cost of settling) .... As the sentence on conviction and the probability of conviction rise, so does the prosecutor's minimum demand." 28 A defendant, meanwhile, comes to plea negotiations with her own settlement offer, dictated by "the sentence [she] expects to receive if convicted," adjusted for the likelihood of conviction, ${ }^{[29]}$ together with the cost savings associated with settlement (as opposed to taking the case to trial). ${ }^{30}$ These offers, both framed with likely trial outcomes in mind, will yield a deal "if the defendant's maximum offer equals or exceeds the prosecutor's minimum demand."31 To Easterbrook, these interactions, repeated across cases, fulfill a "priceestablishing function at low cost," and are therefore "desirable, not just defensible, if the system attempts to maximize deterrence from a given commitment of resources." 32

This view of plea bargaining as a market in which the parties negotiate "in the shadow of trial" has cast a long shadow of its own. ${ }^{33}$ Contemporary analyses of plea bargaining tend to either assume the basic truth of the market model, or espy flaws in it. ${ }^{34}$ As to the latter, Easterbrook provided kindling to critics of his analogy by observing that his analysis proceeded on the assumption that defendants and prosecutors acted as rational maximizers of their respective "satisfactions." "35 Much of the modern debate over plea bargaining has considered what these "satisfactions" are, ${ }^{36}$ and whether the relevant actors are fully capable of appreciating and realizing them. ${ }^{37}$

28. Id. at 297 .

29. Id. at 297, 311-16; see also Adelstein, supra note 25, at 809 (observing that a "defendant will agree to a guilty plea if he perceives the cost of the sentence received upon the plea as less than the expected disutility of the trial prospect and its associated sentence").

30. Easterbrook, supra note 24, at 297.

31. Id.

32. Id. at 309 .

33. See Bibas, supra note 13, at 2464-65 (observing that the "shadow-of-trial model . . looms large in recent plea-bargaining literature"); Russell D. Covey, Signaling and Plea Bargaining's Innocence Problem, 66 WASH. \& LEE L. REV. 73, 77 (2009) ("Trial shadow theory provides the dominant account of plea bargaining."); Harold W. Elder, Trials and Settlements in the Criminal Courts: An Empirical Analysis of Dispositions and Sentencing, 18 J. LEGAL STUD. 191, 199 (1989).

34. The many articles that start from a premise of a plea bargain "market" include Russell D. Covey, Longitudinal Guilt: Repeat Offenders, Plea Bargaining, and the Variable Standard of Proof, 63 FLA. L. REV. 431, 435 (2011) ("Although criminal defendants-like shoppers - do not always get the best bargain possible, plea bargaining - like shopping - can best be understood by looking to the market that sets the relevant prices of the sought-for goods.").

35. Easterbrook, supra note 24, at 291.

36. Jeffrey Standen, An Economic Perspective on Federal Criminal Law Reform, 2 BuFF. CRIM. L. REV. 249, 261-67 (1998) (discussing the motives of the "entrepreneurial prosecutor").

37. These subjects of study are not altogether novel. Decades ago, Albert Alschuler probed the motives of prosecutors and defense attorneys who brokered plea deals. See Alschuler, supra note 13, at 1203-06, 1313 (discussing the incentives that may lead defense attorneys to recommend guilty pleas that are not in their clients' interests); Alschuler, supra note 9. 
Some of the most important literature in this genre has focused on the inability of parties to behave as predicted by the market model. In the opinions of some commentators, information gaps, along with cognitive biases and other "psychological pitfalls," may skew the plea-negotiation process so as to place the bargained-for outcomes outside the shadow of likely trial outcomes. ${ }^{38}$ Stephanos Bibas, in particular, has detailed how information deficits and asymmetries, ${ }^{39}$ overconfidence, ${ }^{40}$ psychological blocks and denial mechanisms, ${ }^{41}$ steep discounting of future incarceration by defendants, ${ }^{42}$ risk aversion, ${ }^{43}$ and framing ${ }^{44}$ and anchoring effects ${ }^{45}$ may produce plea bargains that do not reflect probable trial results, adjusted for the likelihood of conviction. $^{46}$

Another line of inquiry focuses more on how institutional environments affect parties' behavior than on the motives of particular actors in the pleabargaining process. ${ }^{47}$ These analyses ascribe significant effects to factors such as local policies regarding the appointment and payment of counsel; ${ }^{48}$ the government's status as a monopsonist, being the sole producer and distributor of criminal charges; ${ }^{49}$ the relevant prosecutorial authority's stated policies ${ }^{50}$ and

38. Bibas, supra note 13, at 2496-527.

39. Id. at 2493-96.

40. Id. at 2498-502; see also Albert W. Alschuler, The Changing Plea Bargaining Debate, 69 CALIF. L. REV. 652, 664 (1981) ("[D]efendants have refused to plead guilty because of an unrealistic optimism concerning the chances of beating the state's case.").

41. Bibas, supra note 13, at 2502-04.

42. Id. at 2504-07.

43. Id. at $2507-12$.

44. Id. at $2512-15$.

45. Id. at 2515-19.

46. Other works that mine the same vein include Alafair S. Burke, Prosecutorial Passion, Cognitive Bias, and Plea Bargaining, 91 MARQ. L. REV. 183, 192-203 (2007) and Robert E. Scott \& William J. Stuntz, Plea Bargaining as Contract, 101 YALE L.J. 1909 (1992).

47. For an overview of some of these inquiries into "structural" determinants of plea bargaining, see Kay L. Levine, The Intimacy Discount: Prosecutorial Discretion, Privacy, and Equality in the Statutory Rape Caseload, 55 EMORY L.J. 691, 698-99 (2006).

48. Bibas, supra note 13, at 2476-82; Stephen J. Schulhofer, Plea Bargaining as Disaster, 101 YALE L.J. 1979, 1987-91 (1992).

49. E.g., Jeffrey Standen, Plea Bargaining in the Shadow of the Guidelines, 81 CALIF. L. REV. 1471 (1993). According to Standen, as agents of a monopsonist, prosecutors can "obtain exchanges of pleas at subcompetitive prices" and "have an incentive to discriminate against particular defendants or subgroups of defendants by attempting to settle like cases differently depending on defendants' personal characteristics unrelated to culpability." $I d$. at 1473.

50. E.g., Leonard R. Mellon et al., The Prosecutor Constrained by His Environment: A New Look at Discretionary Justice in the United States, 72 J. CRIM. L. \& CRIMINOLOGY 52, 53 (1981) (summarizing findings of a study of ten large prosecutors' offices, to the effect that "in some cases the external environment imposes substantial limits on a prosecutor's ability to act" and that prosecutorial policy "significantly affects the so-called 'discretionary' decisions made by the prosecutorial offices studied"); Ilene H. Nagel \& Stephen J. Schulhofer, A Tale of Three Cities: An Empirical Study of Charging and Bargaining Practices Under the Federal Sentencing Guidelines, 66 S. CAL. L. REV. 501 (1992); Welsh S. White, A Proposal for Reform of the Plea Bargaining Process, 119 U. PA. L. REV. 439, 442 (1971) (discussing the Philadelphia district attorney's policies toward plea bargaining); 
informal customs ${ }^{51}$ regarding charging and bargaining; the inculcation of courtroom norms in new prosecutors and defense attorneys; ${ }^{.2}$ and the availability of bail and competent counsel. ${ }^{53}$ These critiques do not gainsay the importance of individual actors in the plea-bargaining process. They tend to stress, however, how forces outside of the immediate control of any particular prosecutor, defense attorney, or defendant shape the motives and priorities of these actors, and thereby affect the likelihood of plea bargaining and the range of possible outcomes.

Finally, scholars have considered how the architecture of a criminal code and its sentencing provisions can affect plea bargaining. As Ronald Wright and others have explained, ${ }^{54}$ code structure may affect the likelihood and content of plea bargaining in a variety of ways. For one thing, a criminal code that contains overlapping offenses conducive to "charge stacking" can facilitate plea bargaining by incentivizing a defendant to engage in these negotiations (since "stacked" charges threaten increased odds of conviction, and enhanced punishment upon conviction ${ }^{55}$ ) and offering more "landing points" for potential bargains (through withdrawal of one or more of the "stacked" offenses). ${ }^{56}$ Likewise, a criminal code (or sentencing rules applicable to the code) can facilitate plea bargaining by containing relatively "smooth" and "flat" sentencing slopes among related offenses, or chill this practice with dramatic, inflexible sentencing "cliffs" - stark drop-offs in the sentencing consequences attached to lesser offenses that might otherwise represent the basis for plea

Wright \& Miller, supra note 16 (describing how rigorous prefiling screening of criminal cases by a local prosecutor's office may reduce the rate of plea bargains within a jurisdiction).

51. E.g., LYNN M. MATHER, PlEA BARGAINING OR TRIAL? 84 (1979) (describing a practice among California prosecutors of charging defendants in car-theft cases with both grand theft auto and either joyriding or possession of stolen property, with the expectation that the grand theft auto charge would be dismissed pursuant to a plea deal whereby the defendant would plead guilty to the other offense).

52. E.g., Milton Heumann, Plea Bargaining: The Experience of Prosecutors, JUDGES, AND DEFENSE ATTORNEYS (1978) (studying the adaptation process through which new prosecutors and defense attorneys are assimilated into plea-bargaining practices); Terance D. Miethe, Charging and Plea Bargaining Practices Under Determinate Sentencing: An Investigation of the Hydraulic Displacement of Discretion, 78 J. CRIM. L. \& CRIMINOLOGY 155, 157, 174 (1987); Schulhofer \& Nagel, supra note 17, at 1294-96.

53. Bibas, supra note 13, at 2491-93.

54. Wright and Engen's study of portions of the North Carolina criminal code, The Effects of Depth and Distance in a Criminal Code on Charging, Sentencing, and Prosecutor Power, supra note 19 , represents the most thorough assessment of code structure to date, and in its sensitivity to the importance of specific code provisions in determining the likelihood of plea bargaining and the content of these deals, comes the closest to capturing the spirit of this Article.

55. William J. Stuntz, The Collapse of American Criminal Justice 263 (2011); Stuntz, supra note 18, at 519-20.

56. See Russell Covey, Reconsidering the Relationship Between Cognitive Psychology and Plea Bargaining, 91 MARQ. L. REV. 213, 228-29 (2007) (observing that 'prosecutors . . can 'stack' charges carrying mandatory minimums in order to threaten or impose dramatic increases in mandatory sentences after a trial conviction"); Stuntz, supra note 18, at 529-33. 
bargains to more serious crimes. ${ }^{57}$ Mandatory sentencing provisions, meanwhile, can frustrate plea bargaining, or at least force the parties to negotiate the charges of conviction as well as the sentencing terms. ${ }^{58}$ Similarly, I have discussed elsewhere how codes may incorporate "pleading crimes," offenses that encourage plea bargains by providing common ground for these deals. 59

The common problem with these descriptions of plea bargaining is not that they are wrong, but that they tend to be incomplete. The dynamics discussed above are not constant across crimes. The utilization of some crimes comports neatly with the market model, with parties agreeing to a large number of bargains with terms that appear "rational" in light of likely trial outcomes. Other offenses, however, exacerbate cognitive biases or institutional quirks, and thereby produce a relatively high or low number of plea bargains or distinctively lenient or severe deals.

As matters stand, no one has comprehensively examined this missing piece of the plea-bargaining puzzle. ${ }^{60}$ This lacuna reflects a deliberate choice more than a mere oversight. Many observers regard the substance of an offense as a relatively insignificant part of the plea-bargaining and sentencing calculus. In the words of one commentator, when it comes to plea bargaining, specific crimes "do not appear to matter very much any more, if ever they did. They have very little to do with what is most important in a system of criminal justice, which is how and how much justice is meted out to those convicted of crimes."61

Other commentators have considered the plea-bargaining practices that surround a specific type of crime, or studied plea bargaining within a particular jurisdiction or jurisdictions. ${ }^{62}$ These studies, however, tend to group crimes into

57. Bibas, supra note 13, at 2486-91 (describing how sentencing laws often create "slopes" and "cliffs" between crimes, and the effects that these "slopes" and "cliffs" have on plea bargaining); Wright \& Engen, The Effects of Depth and Distance in a Criminal Code on Charging, Sentencing, and Prosecutor Power, supra note 19, at 1954-55 (discussing the importance, in plea bargaining, of the sentencing "distance" between the original charge and viable plea-bargaining "landing points" within a code).

58. E.g., FISHER, supra note 14, at 221-27; Candace McCoy, Plea Bargaining as Coercion: The Trial Penalty and Plea Bargaining Reform, 50 CRIM. L.Q. 67, 84 (2005) ("Prosecutorial dominance over plea bargaining became even more pronounced in the past three decades in the United States with the introduction of mandatory sentencing.").

59. Kyle Graham, Facilitating Crimes: An Inquiry into the Selective Invocation of Offenses Within the Continuum of Criminal Procedures, 15 LEWIS \& CLARK L. REV. 665, 695-702 (2011).

60. Here again, it merits mention that the work of Ronald Wright and Rodney Engen represents a step in the direction pursued by this Article. In their work The Effects of Depth and Distance in a Criminal Code on Charging, Sentencing, and Prosecutor Power, supra note 19, Wright and Engen engage in a thoughtful review of how code structure affects the plea-bargaining patterns associated with certain crimes within the North Carolina code.

61. Standen, supra note 36 , at 252.

62. E.g., Bowers, supra note 23, at 1711-12; Frank O. Bowman III \& Michael Heise, Quiet Rebellion II: An Empirical Analysis of Declining Federal Drug Sentences Including Data from the 
generic categories, from the relatively specific (e.g., "rape," "burglary," and "theft" ${ }^{\text {"63 }) ~ t o ~ t h e ~ m o r e ~ g e n e r a l ~(" d r u g ~ c r i m e s, " ~ " v i o l e n t ~ c r i m e s, " ~ e t c . ~}{ }^{64}$ ). These labels can cloak significant variation among related offenses. ${ }^{65}$ A particular "violent" crime may lead to a high percentage of plea bargains while another "violent" crime yields relatively few. Furthermore, these studies blunt their prescriptive potency by lumping specific crimes into generic offense types. Legislatures create, amend, and abolish individual crimes, not broad crime categories. Prosecutors likewise charge, and defense attorneys parry, specific crimes that carry specific consequences. ${ }^{66}$ To lay a foundation for possible reform, one must delve into the granular provisions of a code, and the chargelevel behavior by courtroom actors.

II.

\section{CRIME CHARACTERISTICS AND PLEA BARGAINING}

Crimes differ from one another in their gravamen, in their consequences upon conviction (or, from the prosecutor's standpoint, upon acquittal), and in many other respects. Yet only some of these differences have a substantial effect upon a crime's conduciveness to plea bargaining.

One way to grasp the significance of charge content upon plea bargaining begins with an oversimplified sketch of the rational-actor model. If one assumes that (1) both sides in a criminal case have perfect information as to the likelihood of acquittal at trial, (2) the custody time that the defendant will receive upon conviction represents the exclusive concern of both the prosecution and defense (with the prosecution intent upon maximizing this figure, and the defense seeking to minimize it), and (3) there exist infinite pleabargaining options that will allow the parties to agree upon any and all possible custodial terms, then very few cases should go to trial. The characteristics of many crimes, however, throw sand into the gears of this model. With some

District Level, 87 IOWA L. REV. 477 (2002); Stuntz, supra note 15, at 2563-64 (generalizing and juxtaposing the plea-bargaining practices believed to surround "violent crimes" on the one hand and "drug crimes" on the other).

63. E.g., Thomas H. Cohen \& Tracey Kyckelhahn, Felony Defendants in Large URBAN COUNTIES, 2006, at 11 (2010) (relating adjudication outcomes for various types of felony defendants).

64. E.g., Stuntz, supra note 15 , at 2563-64.

65. To similar effect, in discussing case outcomes across the federal criminal "code," the Sourcebook of Criminal Justice Statistics groups related crimes into one of approximately one hundred generic offense types. BUREAU OF JUSTICE STATISTICS, SOURCEBOOK OF CRIMINAL JUSTICE STATISTICS ONLINE, tbl.5.24.2010 (2010), http://www.albany.edu/sourcebook/pdf/t5242010.pdf. Since each of these categories subsumes several specific crimes, the reported data regarding the sorts of criminal cases that are prosecuted in federal court says very little about the utilization of individual offenses.

66. Wright \& Engen, The Effects of Depth and Distance in a Criminal Code on Charging, Sentencing, and Prosecutor Power, supra note 19, at 1953 ("Prosecutors and defense attorneys negotiate about guilty pleas for particular crimes, not just generic classes of felonies.”). 
offenses, there may be little available information regarding trial outcomes, taking a case to trial may have significant irreplaceable value, and pleabargaining options may be relatively limited or unattractive compared to those that appear with other crimes. ${ }^{67}$

\section{A. Incomplete or Imperfect Information}

First, crimes vary in the extent to which the parties will possess accurate information regarding likely trial outcomes. When prosecutors and defense attorneys lack this information for a given crime, they will be more prone to disagree as to the probable result at trial, leading to more trials for that offense. ${ }^{68}$ As related below, these disagreements are more likely to arise with crimes that are difficult to prove or are not alleged with substantial frequency.

67. The discussion above does not necessarily exhaust the ways in which crimes may vary in a manner relevant to plea bargaining and trial rates and outcomes. For example, though some crimes cleave relatively evenly across race, wealth, gender, occupation, and other pertinent demographic facts, others do not. See, e.g., Bureau OF Justice Statistics, SourceboOK OF CRiminal Justice STATISTICS ONLINE, tbl.5.39.2010 (2011), http:/www.albany.edu/sourcebook/pdf/t5392010.pdf (relating that African Americans accounted for 78.5 percent of defendants sentenced for federal crimes involving crack cocaine in fiscal year 2010, as compared to only 26.8 percent of defendants sentenced for federal crimes involving powder cocaine, and 7.6 percent of defendants sentenced for federal crimes involving marijuana). These differences can affect plea bargaining and trial outcomes in a variety of ways. As will be discussed, some crimes may tend to implicate defendants as to whom juries are relatively prone to exercise their nullification authority. Other crimes, such as insider-trading offenses, tend to involve well-heeled defendants with significant resources to fight the charges alleged against them, and who may be in a position to negotiate more advantageous pleas. See EISENSTEIN \& JACOB, supra note 17, at 234-35, 241-42 (discussing the perception that affluent defendants are more likely to mount vigorous defenses, and related data that suggest that defendant characteristics have a modest to moderate effect on case dispositions); Bowers, supra note 23, at 1711-12 (describing these issues as they pertain to potential prosecutions for obscenity and white-collar crimes). At the other extreme, some crimes tend to involve defendants who, due to language barriers, a lack of education, or otherwise, may be incapable of robust participation in the strategic planning and assessment of their cases. This disability may lead to the abdication of plea-bargaining authority to defense attorneys, who may not always be acting in their principals' best interests. Bibas, supra note 13, at 2476-80.

68. MATHER, supra note 51, at 143 (finding, based on a study of California plea-bargaining practices, that "[d]isagreement between defense and prosecuting attorney over the basic question of legal guilt was [an] important factor leading to adversary trial”); Elder, supra note 33, at 196 ("One conclusion of economic models of the courts is that the more agreement there is in the estimates by both sides of the likely outcome of a trial, the lower the probability of a trial."'); $i d$. at 199 (concluding, based on a regression analysis, that "[f]actors increasing agreement between defendant and prosecution increase the probability of settlement"); see also George L. Priest \& Benjamin Klein, The Selection of Disputes for Litigation, 13 J. LEGAL STUD. 1, 12-17 (1984) (observing that civil cases will tend to settle when the applicable law, and likely result at trial, are clear to the parties). 


\section{Ease or Difficulty of Proof}

Some crimes are easier to prove than others are. ${ }^{69}$ All else being equal, the more difficult a crime is to prove, the greater incentive the prosecution has to plea bargain, ${ }^{70}$ and the more leverage the defense has to demand a significant sentence discount. ${ }^{71}$ One might surmise, then, that crimes that are more difficult to prove at trial will tend to produce more plea bargains, as opposed to pleas to the charged offense(s) without any promised reduction in sentence terms. Less obviously, these offenses also may produce a relatively large share of trials instead of guilty pleas, since high acquittal rates create room for differences of opinion as to the likely outcome at trial, which will lead to divergent settlement demands.

Some crimes implicate proof that brooks little dispute, while other offenses tend to involve evidence that is much more conducive to conflicting interpretations. For an example of a crime that is easily proved, consider 8 U.S.C. $§ 1326$, which criminalizes the reentry of a deported person into the United States. $^{72}$ In a mine-run case, this crime simply requires that the prosecution establish that the defendant alien (1) had been deported from the United States; (2) was later found in the United States; and (3) intended to

69. EISENSTEIN \& JACOB, supra note 17, at 235 ("While every offense must be proved 'beyond a reasonable doubt,' the statutory provisions of the criminal code require varying kinds of evidence that make some crimes easier to prove than others."); Stuntz, supra note 18, at 550-51 (discussing the relative ease and difficulty associated with proving different crimes). Crimes that have been identified, by one source or another, as particularly difficult to prove at trial include "complex financial cases," Jean Eaglesham, Financial Crimes Bedevil Prosecutors, WALl ST. J., Dec. 6, 2011, at $\mathrm{C} 1$ (describing these crimes as "especially hard to prove"); vehicular manslaughter, Vivian Huang, Few Found Guilty in Car Deaths, N.Y. DAILY NEWS, Nov. 19, 1995, at Suburban1; and rape, Thomas A. Mitchell, We're Only Fooling Ourselves: A Critical Analysis of the Biases Inherent in the Legal System's Treatment of Rape Victims, 18 BUFF. J. GENDER, L. \& SOC. POL'Y 73, 76 (2010), just to name a few.

70. See, e.g., Donald J. Newman, Conviction: The Determination of Guilt or INNOCENCE WITHOUT TRIAL 55 (1966) ("Confronted with cases involving crimes like adultery or situations where a victim is more disreputable than the defendant, the prosecutor, doubtful of jury reaction, will often reduce the charge to a point where the defendant will plead guilty."); White, supra note 50, at 445 (observing that, in Philadelphia, "likelihood of conviction is generally very important in determining what concessions will be offered to induce a plea. While some trial prosecutors enjoy the challenge of a difficult case, most will offer substantial concessions rather than risk losing a jury trial"); id. at 448 (discussing the same pattern, among New York City district attorneys).

71. See Oren Gazal-Ayal, Partial Ban on Plea Bargaining, 27 CARDOzo L. Rev. 2295, 2313 (2006) ("A defendant who knows that the probability of acquittal at trial is substantial will only agree to plead guilty in return for an exceedingly lenient bargain. In stronger cases, the prosecutor will not offer exceedingly lenient bargains, knowing that the defendant will settle for much less."); Mellon et al., supra note 50 , at 78 (observing that "a disposition by a plea is more likely to occur as the evidentiary strength of the case is reduced").

72. With limited exceptions, 8 U.S.C. § 1326 makes it a federal crime for someone who "has been denied admission, excluded, deported, or removed or has departed the United States while an order of exclusion, deportation, or removal is outstanding," to thereafter enter, attempt to enter, or be at any time found in the United States. 8 U.S.C. $§ 1326$ (2006). 
reenter the United States. ${ }^{73}$ The first element is typically established by an order of deportation; the latter two, by testimony to the effect that the defendant subsequently was found in the United States. This evidence tends to permit little debate as to the defendant's intent or any other element of the crime. ${ }^{74}$ The prosecution has little incentive, other than avoiding the hassle of trial, to offer generous bargains in these cases. ${ }^{75}$

At the other pole, some crimes are difficult to prove because the evidence commonly relied upon to show guilt is ambiguous or subject to impeachment. For example, it is sometimes said that crimes that require fraudulent or specific intent are difficult for prosecutors to establish. ${ }^{76}$ Perjury, in particular, is oftentimes described as challenging to prove. ${ }^{77}$ But not all variants of perjury are equally situated in this respect. Perjury in connection with one's tax returns may be relatively easy to show, since we assume that most people know roughly how much money they make. ${ }^{78}$ Trial perjury, on the other hand, can be more difficult to prove, since the circumstances that tend to surround this offense make it much more difficult to rule out alternative explanations (such as simple forgetfulness) for the false statements at issue.

In addition to problems of proof, juries may refuse to return a conviction for a crime if they feel that the law is wrong-headed or have special sympathy

73. United States v. Carlos-Colmenares, 253 F.3d 276, 277-78 (7th Cir. 2001).

74. Judge Richard Posner has hypothesized the case of a previously deported person involuntarily transported into the United States by a hijacker, $i d$. at 278 , but this fact pattern seems rather unlikely to occur very often. But cf. STEVEN F. HUBACHEK \& SHEREEN J. CHARLICK, Testimony of Steven F. Hubachek and Shereen J. Charlick, Supervisory Attorneys of Federal Defenders of San Diego, Inc., Before the United States Sentencing Commission Concerning Fast Track or Early Disposition Programs 5 (2003), available at http://www.ussc.gov/Legislative_and_Public_Affairs/ Public_Hearings_and_Meetings/20030923/hubachek.pdf [hereinafter Hubachek Testimony] (stating that $\S 1326$ cases sometimes involve "difficult legal issues").

75. See Wright \& Engen, The Effects of Depth and Distance in a Criminal Code on Charging, Sentencing, and Prosecutor Power, supra note 19, at 1967 (speculating that with some easy-to-prove crimes, charge bargaining may be unavailable as an option because defendants "have little value to offer in exchange for a reduced charge").

76. See, e.g., United States v. Lockhart, 167 F. App'x 111, 112 (11th Cir. 2006) (observing that it can be difficult to prove fraudulent intent); United States v. Bradfield, 225 F.3d 660 at *9 (6th Cir. 2000) ("Specific intent is . . the most difficult state of mind for a prosecutor to prove."); Lisa M. Fairfax, Form over Substance?: Officer Certification and the Promise of Enhanced Personal Accountability Under the Sarbanes-Oxley Act, 55 RUTGERS L. REV. 1, 52-53 (2002) (discussing the difficulties associated with establishing criminal intent in financial fraud cases).

77. See, e.g., United States v. Harris, 67 M.J. 611, 615 (A.F. Ct. Crim. App. 2009) (“[P]erjury is a notoriously difficult charge to prove."); Ken Armstrong, Hard to Prove, Perjury Often Goes Unpunished, CHI. TRIB., Sep. 25, 1998, at A1; Bob Egelko, Perjury Always a Tough Charge to Prove in Court, S.F. CHRON., Apr. 15, 2006, at A1.

78. See United States v. Boulerice, 325 F.3d 75, 80 (1st Cir. 2003) (observing that circumstantial evidence can suffice to establish the "willfulness" intent requirement in a prosecution under 26 U.S.C. $§ 7203(1)$, which criminalizes the willful and knowing utterance of material false statements on a tax return). 
for a defendant. ${ }^{79}$ Jury nullification is a longstanding practice. In the $1850 \mathrm{~s}$ northern juries refused to return guilty verdicts in cases brought under the Fugitive Slave Act. ${ }^{80}$ Prohibition-era juries declined to convict defendants who committed liquor-law violations. ${ }^{81}$ Modern juries may be "balking in trials in which a conviction could trigger a 'three strikes' or other mandatory sentence, and in 'assisted suicide,' drug possession, and firearms cases." ${ }^{, 2}$ As these examples suggest, the concerns that encourage nullification do not cleave evenly across crimes. $^{83}$

One might think that prosecutors would account for these difficulties in case selection. And to an extent, they do. ${ }^{84}$ But there may exist political or other pressures to file certain types of cases even when prosecutors anticipate a relatively high likelihood of acquittal. Or prosecutors might be personally convinced that the charges are just and well-founded, even if they anticipate that a jury might disagree. ${ }^{85}$ Furthermore, prosecutors may be unable to reliably forecast how jurors will assess some types of cases. The outcomes in cases that depend heavily on a jury's visceral response to the witnesses at trial, for example, may be difficult for prosecutors to predict. In such matters, prosecutors may be unable to avoid a high acquittal rate across cases, even if they cannot anticipate that any given case is particularly likely to result in a not-guilty verdict.

79. See Nancy S. Marder, The Myth of the Nullifying Jury, 93 Nw. U. L. REV. 877, 887-903 (1999) (describing a variety of situations in which juries may exercise their nullification power).

80. Id. at 892-93; see also Nancy J. King, Silencing Nullification Advocacy Inside the Jury Room and Outside the Courtroom, 65 U. CHI. L. REV. 433, 460-62 (1998) (discussing the steps taken to avert nullification). Going even further back in time, John Langbein has catalogued how London juries in the 1750s frequently returned only "partial verdicts" in certain types of criminal cases. These verdicts convicted defendants only of lesser crimes than those charged in the indictments. For example, a defendant charged with pickpocketing a shilling or more was commonly convicted only of pickpocketing less than a shilling, a switch that transformed a capital offense into one punishable only by transportation to the American colonies for a period of indentured servitude. John H. Langbein, Shaping the Eighteenth-Century Criminal Trial: A View from the Ryder Sources, 50 U. CHI. L. REV. 1, 37, 52-53 (1983).

81. Marder, supra note 79, at 894-95.

82. King, supra note 80 , at 433.

83. Furthermore, there exist some crimes where the jury, though not prone to outright nullification, may be inclined to give the defendant the benefit of every doubt, reasonable or not. See KALVEN \& ZEISEL, supra note 9, at 286-97 (discussing several "unpopular" crimes, as to which juries are relatively prone to acquit).

84. See infra text accompanying note 227.

85. For such a case, consider the trial, and retrial, of Byron de la Beckwith, accused (and, decades later, convicted) of the murder of civil rights activist Medgar Evers. The prosecutor, William Waller, retried the case even after the first trial resulted in a hung jury. See Second Beckwith Trial Begins Tomorrow, Delta Democrat-Times (Greenville, MS), Apr. 5, 1964, at 1. Even in the initial trial, "a quick acquittal had been freely predicted," given the place, time, and composition of the jury. Mistrial Stuns Confident Byron, LAURel Leader-Call, Feb. 8, 1964, at 1. Likewise, federal prosecutors who brought civil rights charges against public officials back in the 1960s and 1970s had such a dismal conviction rate that they must have foreseen a high likelihood of acquittal in many cases that they filed and tried. See infra text accompanying note 226. 
The market model accounts for variation in "provability," insofar as it acknowledges that the likelihood of conviction at trial will affect the content of a plea bargain. ${ }^{86}$ Per the model, as the odds of acquittal increase, so too does the sentencing "discount" that the defendant will demand, and receive ${ }^{87}$ The model says little, however, about any connection between provability and the frequency of pretrial pleas. Given the assumptions incorporated into the model, difficult-to-prove crimes should result in just as high a percentage of pleas as easily proved crimes do - only the terms will change.

Of course, these assumptions are never satisfied; that is the key lesson taught by the works of Bibas, Wright, and others. Given realistic conditions, the leading authorities seem to disagree about whether easy or hard cases are more susceptible to pleas, and plea bargaining. In their seminal work, The American Jury, Harry Kalven Jr. and Hans Zeisel surmised that the "strongest" cases, from the prosecutor's perspective, would tend to produce guilty pleas, leaving relatively weak cases for trial. ${ }^{88}$ More recently, Bibas has suggested that the opposite may be true, at least in certain types of cases. Prosecutors suffer from loss aversion, he observes, and may be more inclined to bargain in weaker cases, leading to more pleas in these matters. ${ }^{89}$

It is possible that both views are correct. Here, it is important to distinguish between pleas and plea bargaining. In some especially strong cases, the defendant might simply "plead to the sheet" "90 even without any promises of leniency from the prosecution. This amounts to capitulation, not bargaining, and normally bespeaks a compelling prosecution case. Insofar as true bargaining is concerned, Kalven and Zeisel may have identified a consequence of imperfect information. Crimes that are relatively difficult to prove often implicate a greater range of uncertainty than easily proved crimes do. For example, the prosecutors and defense attorneys in a given federal jurisdiction may understand that a typical 8 U.S.C. $\S 1326$ charge likely has between a 92 percent and 98 percent chance of leading to a conviction at trial, while a normal count under 18 U.S.C. $\S 242$ has anywhere between a 40 percent to a 70 percent chance of resulting in a conviction. The enhanced uncertainty that adheres to 18 U.S.C. $\S 242$ charges leaves more room for disagreement between the parties as to the probable result at trial. This disagreement may prevent the parties from settling upon the terms of a "fair" bargain to an 18

86. Easterbrook, supra note 24, at 312-13.

87. Id. at 312 .

88. KALVEN \& ZEISEL, supra note 9, at 30.

89. Bibas, supra note 13, at 2472-73.

90. Prosecutors and defense attorneys use a variety of terms to describe a guilty plea to all charges filed in a case, with no prior agreement regarding the sentence to be recommended to the judge. When he was a deputy district attorney, the author was taught that this transaction amounted to a "plea to the sheet." Other phrases that describe the same practice include "open plea" and "pleading straight up." 
U.S.C. § 242 charge. This stalemate will lead to fewer plea bargains and more trials in cases involving this crime.

At the same time, Bibas also may have a point. While difficult-to-prove crimes may produce more trials, on average, than their more straightforward counterparts do, as to any particular crime this influence may be more than counterbalanced by other factors. Prosecutors may take certain types of challenging but high-profile cases to trial relatively often, to showcase their office's commitment to pursuing the charged offenses. ${ }^{91}$ Likewise, some hardto-prove crimes might claim particularly attractive "landing points" for plea bargains; ${ }^{92}$ or the prosecution and defense may be capable of pinpointing and agreeing upon the relatively high odds of acquittal for some charges. In other words, consideration of a crime's conduciveness to proof is necessary, but insufficient, to ascertain the likelihood of a plea or trial, and the relative leniency or harshness of probable plea terms.

\section{Case Volumes}

As to any crime, the existence of a large body of previously resolved cases that alleged the offense will tend to increase the frequency of future plea bargains and narrow the range of outcomes in these later-arising matters. There exist two reasons for this dynamic. First, a high volume of cases produces more robust and readily available information regarding the likelihood of conviction at trial, the "going rate" for a plea bargain, or both. Second, frequent prosecution will produce specialist practitioners with enhanced case-assessment capabilities.

As to the first of these consequences of high filing rates, it may take time, and many prosecutions, to appreciate how simple or difficult it is to convict a defendant of a particular crime. ${ }^{93}$ Practitioners know that it is easy to convict a defendant of a garden-variety illegal reentry charge under 8 U.S.C. $\S 1326$. This knowledge represents the accumulation of many years' worth of prosecutions. Other crimes claim no equivalent body of work. While there exist, by one estimate, 4450 federal crimes,${ }^{94}$ in a given year fewer than 2000 offenses are actually alleged in federal prosecutions. ${ }^{95}$ Moreover, most cases

91. See infra text accompanying notes 104-09.

92. See infra text accompanying notes $130-34$.

93. A similar dynamic applies to attorneys, as well as crimes; it takes time for a defense attorney or prosecutor to develop a "feel for a case," so as to know whether to plea bargain the case, or take it to trial. See HEUMANN, supra note 52, at 76, 102-03.

94. Baker, supra note 22, at 1.

95. Kyle Graham, Sandusky's Law, CONCURRING OPINIONS (Dec. 5, 2011, 1:38 PM), http://www.concurringopinions.com/archives/2011/12/sandusky\%E2\%80\%99s-law.html (reviewing data culled from Executive Office of the United States Attorneys charging files). Notwithstanding the juxtaposition of the 4450 and 1500 figures above, one must resist the temptation to compare the two figures; counting crimes is a highly subjective task, and different methodologies may lead to quite different totals. 
tend to implicate the same handful of charges. In one recent fiscal year (2009), fewer than 20 crimes accounted for more than half of all federal counts filed, and fewer than 300 crimes accounted for 95 percent of all such counts. ${ }^{96}$ Many crimes thus have no opportunity to develop a reputation as easy or difficult to prove. With these rarely charged crimes, parties and their attorneys must speculate as to the "shadow of trial," rather than having past results (or the customary terms of plea deals) upon which to base their bargains. These predictions may vary, leading to more trials and fewer plea bargains. ${ }^{97}$

In a similar spirit, more prosecutions for an offense within a particular jurisdiction will produce enhanced case-assessment skills among prosecutors and defense attorneys. These skills will lead to more plea bargains for that crime, since the attorneys will be better able to ascertain likely trial outcomes. ${ }^{98}$ In this respect, case volumes also can have a more subtle and nonlinear effect on plea bargaining. A prosecutor who rarely, if ever, charges a particular crime may not appreciate how difficult it will be to prosecute that offense; a defense attorney rarely tasked with the opposite responsibility may find herself equally at a loss. While these uncertainties might cancel each other out, they also leave the parties susceptible to cognitive biases that tend to deter or skew plea bargaining.

These dynamics change as the number of cases charging an offense increases. At a slightly higher volume of cases, prosecutorial capabilities may tend to exceed defense skills, since these cases will be spread out among defense attorneys and concentrated within a single prosecuting entity (which may dedicate a particular prosecutor, or group of prosecutors to specialize in these cases). This imbalance may lead to plea-bargain terms more favorable to the prosecution. When a crime is charged often enough, however, a specialized defense bar will develop (or generalist defense attorneys will cultivate sufficient skill) to effectively counter the prosecution, leading to more defensefriendly bargains.

\section{B. Trial Costs and Value}

Another dimension along which crimes vary in a manner material to plea bargaining concerns the costs and benefits (both broadly defined) associated with the trial of a particular offense, relative to the outlays and gains associated with a pretrial plea to that crime. As avoidable trial costs increase, so too will a party's interest in resolving the case by way of a plea. Meanwhile, trials sometimes provide value to the prosecution or the defense that no plea bargain can capture.

96. Id.

97. See sources cited supra note 68.

98. See HEUMANN, supra note 52, at 76, 102-03 (discussing the development of a "going rate"); Easterbrook, supra note 24, at 310 ("The specialized bar or office also is able to obtain and use, at low cost, information about 'the going rate' for particular offenses."). 
Crimes vary in how costly they are to defend at trial. A defendant may choose to enter a guilty plea to a crime simply to avoid the financial costs of trial, even when the plea carries almost the same punishment as a conviction following trial would. ${ }^{99}$ These out-of-pocket and opportunity-cost considerations may loom especially large in cases that threaten relatively little punishment. Some defendants in misdemeanor cases, for example, might think it better simply to plead guilty to the charged offense than to incur the substantial costs associated with trial, which will be expended regardless of whether the defendant is convicted or acquitted.

Nonpecuniary "costs" also vary across crimes. Especially when particularly stigmatic misdemeanors are involved, defendants may prefer relatively quiet pretrial pleas to the exposure of a public trial. "Morals" crimes such as solicitation of a prostitute, public intoxication, or indecent exposure fall within this sphere of crimes as to which the "costs" of trial, capable of avoidance through a pretrial plea, often involve more than merely financial expenditures. ${ }^{100}$

Trials impose costs on the prosecution as well. As with the defense, the expense of trying a case consists of both the opportunity cost of the prosecutor's time and the actual financial cost of trying a case. ${ }^{101}$ Compare, for example, two hypothetical misdemeanor cases that carry similar prospective punishments. The first involves simple battery, the second a driving under the influence charge. Absent unusual facts, the first case is unlikely to be particularly expensive or time consuming to try. The DUI case, on the other hand, may be significantly more costly. Most notably, modern DUI trials typically require expert testimony. ${ }^{102}$ These additional witnesses not only drive up the financial cost of trying a case from the state's perspective; they also make the case longer, and thus more demanding of the prosecutor's finite time. Presumably, this additional "cost" increases the prosecutor's incentive to negotiate a deal. ${ }^{103}$

99. See Albert W. Alschuler, Implementing the Criminal Defendant's Right to Trial: Alternatives to the Plea Bargaining System, 50 U. CHI. L. REV. 931, 952-55 (1983); Bowers, supra note 23 , at $1708-09$.

100. See, e.g., Steve Kornacki, Larry Craig's Plea: Rationality, Not 'Panic,' N.Y. OBSERVER, (Aug. 31, 2007, 4:23 PM), http://www.observer.com/2007/larry-craigs-plea-rationality-not-panic (by entering a plea to morals offenses, former United States Senator Larry Craig kept "his secret safe for more than two months. Had he lawyered up and fought the charges, we would have known instantly").

101. See Standen, supra note 36, at 259 ("In the disposition of [a] case by plea ... punishment resources are exchanged for prosecutorial resources, as the prosecutor trades a selected term of imprisonment ... for a savings in expenditures of his resources.”).

102. Michael M. Brewer, Tactically Developing Your CaSe 2 (2008) ("DUI cases almost always involve the use of expert scientific testimony by a government criminalist.").

103. See Easterbrook, supra note 24, at 297 (describing the difference between trial costs and settlement costs as bearing upon the prosecution's incentive to agree to a plea deal, as opposed to taking a case to trial). 
While trials carry costs, they also may have unique and irreplaceable value. For a defendant, a trial may represent the only way to gain a public hearing on an asserted defense, showcase what the defendant believes to be an unjust law, or draw attention to an improper application of that law. The "value" of a trial in these cases, in the defendant's view, simply cannot be realized by plea bargaining.

A similar "no compromise" situation can arise when the prosecutor seeks the maximum possible punishment for a criminal act or acts, or insists upon a conviction for a particular crime, instead of a substitute offense. ${ }^{104}$ If the prosecution insists upon the death penalty in a particular case, for example, trial is virtually assured. ${ }^{105}$ Likewise, when prosecutors want to highlight their dedication to strict enforcement of a particular law, or type of laws, ${ }^{106}$ rejecting any plea bargains and taking these cases to trial unless the defendant "pleads to the sheet" represents a very visible means of displaying this commitment. ${ }^{107}$ These interests overlap and function to chill plea bargaining for serious, highprofile crimes. Murder cases tend to produce more trials (and acquittals) than most other crimes do, ${ }^{108}$ and local bans or limits on plea bargaining tend to apply only to deals involving serious or violent crimes. ${ }^{109}$

104. See David Sudnow, Normal Crimes: Sociological Features of the Penal Code in a Public Defender Office, 12 SOC. PROBS. 255, 274 (1965) (describing certain types of criminal cases, including "murders, embezzlements, multiple rape cases ..., large scale robberies, [and] dope ring operations" that "arouse public attention and receive special notice in the papers" and as to which "even were a guilty plea available, both parties feel uncomfortably obliged to bring issues of moral character into the courtroom").

105. See Samuel R. Gross, Lost Lives: Miscarriages of Justice in Capital Cases, 61 LAW \& CONTEMP. PROBS. 125, 145 (1998) ("In many capital cases ... there is no plea bargaining.").

106. See Bibas, supra note 13, at 2472 (observing that ambitious prosecutors "may push strong or high-profile cases to trial to gain reputation and marketable experience"); Covey, supra note 56, at 230 (noting that in "high-visibility" cases, "prosecutors (and judges) are less likely to negotiate unduly lenient deals").

107. In this general vein, some crimes fall within the purview of prosecutors who are tasked with the enforcement of specific laws, and who may represent relatively picky "consumers" of crimes for plea-bargaining purposes. These specialists may consider themselves obligated to obtain convictions for particular crimes (and may have their effectiveness gauged by their success in obtaining these convictions), and thus prefer trials over negotiated pleas to "generic" offenses. The attorneys who work for the Criminal Section of the United States Department of Justice's Civil Rights Division, for example, may balk at plea deals to standard assault charges that forego the constitutional component of a charged case; prosecutors tasked with prosecuting public-corruption offenses might have similar incentives. The author thanks Stephanos Bibas for this insight.

108. Bureau of Justice Statistics, Sourcebook of Criminal Justice Statistics ONLINE, tbl.5.34.2010 (May 28, 2011), http://www.albany.edu/sourcebook/pdf/t5342010.pdf (relating that in more than 30 percent of federal murder cases with sentences issued under the Federal Sentencing Guidelines in fiscal year 2010, the conviction was gained by way of trial一a figure far higher than that accompanying any other category of offense); COHEN \& KYCKELHAHN, supra note 63 , at 11,16 (showing that a significantly higher percentage of murder, voluntary manslaughter, and voluntary homicide cases were resolved through trials, as compared to cases alleging other felony offenses, in the surveyed large urban counties); Stuntz, supra note 15, at 2563 ("In murder cases, prosecutors generally pursue every case they can, which is why the acquittal rate in such cases is so much higher than for felonies generally. Cases cannot be dropped out of fear that the defendants might 
The expressive importance to prosecutors of obtaining a conviction for a particular offense underscores how these actors may not be exclusively concerned with maximizing punishment in a particular case. ${ }^{110}$ Imagine, for example, a strong, high-profile insider trading case in which the maximum possible sentence consists of two years in prison. The defense approaches the prosecution with the following settlement offer: the defendant will agree to serve the full two-year term, but on the condition that she plead guilty to only a (factually supported, but as yet uncharged) count of misprision of a felony, ${ }^{111}$ to be alleged in a superseding indictment to be filed. I do not believe that all, or even most, prosecutors would accept this proposal, even though it removes any uncertainty associated with trial and would grant the prosecution the full quantum of custody it could obtain after trial on the charged offense. If this suspicion is correct, the reason must lie in the fact that with some crimes, prosecutors care first and foremost about obtaining a conviction for the charged offense. No plea deal to a different crime, regardless of its custody terms, will capture the same gains for the prosecution.

\section{Limited and Expansive Compromise Options}

Finally, crimes also differ in the number and relative attractiveness of plausible plea-bargaining options that are available to the parties.

As previously discussed, as the odds of conviction decrease, the prosecutor presumably will become more willing to reduce her punishment demand. There are three ways that such a reduction may occur: the charge itself

win at trial; voters may forgive an acquittal, but they surely won't forgive blowing off a homicide."); see also MATHER, supra note 51, at 142 (finding, upon a study of California plea-bargaining practices, that "[ $\mathrm{t}]$ he most important factor leading to a full court or jury trial was disagreement between defense and prosecution over the sentence in cases where severe punishment was likely"); Elder, supra note 33, at 199 (concluding from an empirical study that "factors increasing the stakes [of a criminal case] reduce the probability of settlement"); Mellon et al., supra note 50, at 77 (finding that the most serious, high-priority cases "generally go[] to trial").

109. For examples of prosecutors who have announced no-plea-bargaining policies as to violent crimes, see Pam Belluck, Queens Prosecutor Bans Plea Bargaining in Felony Cases, N.Y. TIMES, May 16, 1996, at B3; Jean Davidson, Prosecutors Limit Plea Bargaining, CHI. TRIB., Dec. 16, 1982, at NW2; Ian Fisher, Bronx District Attorney Moves to Ban Plea Bargains in Felony Cases, N.Y. TIMES, Nov. 25, 1992, at B3; Rob Johnson, No Deals for Violent Crimes, D.A. Says, COM. APPEAL (Memphis, TN), Dec. 20, 1996, at Al; Leslie Reed, County Attorney: No More Plea Deals, OMAHA WORLD-HERALD, Jan. 3, 2009, at 1A.

110. $C f$. Richard T. BOYlan \& CHERYL X. LONG, Size, MONITORING, AND PleA RATE; AN EXAMINATION OF UNITED STATES ATTORNEYS 17 (2000) (assuming that, in negotiating plea agreements, prosecutors seek to maximize the amount of time that defendants spend in custody); Standen, supra note 36 , at 259 (observing that "[t]hrough charging decisions, the federal prosecutor owns the goods that the criminal justice system allocates: terms of imprisonment").

111. Whoever, having knowledge of the actual commission of a felony cognizable by a court of the United States, conceals and does not as soon as possible make known the same to some judge or other person in civil or military authority under the United States, shall be fined under this title or imprisoned not more than three years, or both.

18 U.S.C. $\$ 4$ (2006). 
could permit negotiations over punishment upon conviction; the case could involve multiple charges, such that the parties can arrive upon more lenient punishment terms simply by agreeing that one or more charges will be dismissed in return for a guilty plea to another charge or charges; or the parties could agree to substitute altogether different charges for those originally alleged in the case. Crimes are not equally situated insofar as these forms of "sentence bargaining" or "charge bargaining" are concerned. ${ }^{112}$ With some crimes, mandatory minimum sentences (or other nonnegotiable components of punishment) may block the first path to disposition by plea, while the second and third approaches may be stymied by a dearth of mutually agreeable charge permutations or alternatives.

All else being equal, mandatory sentences will frustrate plea bargaining by limiting the parties' ability to negotiate acceptable terms. ${ }^{113}$ More broadly, a defendant might be relatively uninspired to enter a guilty plea to a crime for which a large share of the punishment represents an unavoidable incident of any conviction, whether by plea or trial. Along with custody time, conviction can also lead to fines, ${ }^{114}$ property forfeitures, ${ }^{115}$ deportation, ${ }^{116}$ registration as a sex offender, ${ }^{117}$ restrictions on voting ${ }^{118}$ and gun-ownership rights, ${ }^{119}$ preclusion from certain types of employment, ${ }^{120}$ a wide variety of probation conditions, $^{121}$ and stigma. ${ }^{122}$ Some of these consequences may be

112. There exist two basic types of plea bargains: charge bargains and sentence bargains.

The prosecutor can either reduce the charge to one with a lower average penalty than the charge the defendant is facing, or offer a sentence more lenient than average by agreeing to a sentence at the low end of the applicable range of sentences for the charge. These processes are generally referred to as "charge bargaining" and "sentence bargaining."

Birke, supra note 9, at 219-20.

113. See id. at 226 ("[T]he existence of a mandatory sentencing regime increases the punishment value of a plea more than it increases the punishment value of a trial, and should militate in favor of more trials."); Easterbrook, supra note 24, at 298 (noting that mandatory penalties may make settlements less frequent, insofar as they may decrease the gains of trade).

114. See U.S. SENTENCING GUIDELINES MANUAL, supra note 5, § 5E1.2 (relating Guideline ranges for fines).

115. See Catherine E. McCaw, Asset Forfeiture as a Form of Punishment: A Case for Integrating Asset Forfeiture into Criminal Sentencing, 38 AM. J. CRIM. L. 181, 193 (2011) (discussing how criminal forfeiture proceedings work).

116. AM. BAR ASS'N COMM'N ON EFFECTIVE CRIMINAL SANCTIONS \& THE PUB. DEFENDER SERV. FOR THE D.C., INTERNAL EXILE: COLlATERAL CONSEQUENCES OF CONVICTION IN FEDERAL LAWS AND REGULATIONS 43-45 (2009).

117. Id. at $41-42$.

118. Id. at 15 .

119. Id. at $42-43$.

120. Id. at 19-27.

121. See Andrew Horwitz, Coercion, Pop-Psychology, and Judicial Moralizing: Some Proposals for Curbing Judicial Abuse of Probation Conditions, 57 WASH. \& LEE L. REV. 75, 110-53 (2000) (relating a wide variety of probation conditions); Note, Judicial Review of Probation Conditions, 67 COLUM. L. REV. 181, 182-88 (1967) (same).

122. "Stigma is characterized as an external incentive founded on the reluctance of individuals to interact with a person who breaches social norms. Stigma can be either economic (for example, lower wages) or social (for example, difficulty in finding a spouse)." Alon Harel \& Alon Klement, The 
nonnegotiable, in that the plausible plea options do not allow the defendant to avoid them. If so, the value of a guilty plea or plea bargain will be correspondingly less to the defense, and the defendant will be relatively inclined to go to trial. Hence, once might expect to see relatively high trial rates for a crime such as possession of child pornography, given the enormous stigma (and notoriety) that attaches to any and all convictions (whether by plea or by trial) for this offense. ${ }^{123}$ And this supposition appears to be at least partially correct. While trial rates for charges brought under 18 U.S.C. $\S 2252$ (a) and 18 U.S.C. $\S 2252 \mathrm{~A}$ (the key federal possession of child pornography crimes) ${ }^{124}$ are in fact somewhat lower than the average across all federal crimes, ${ }^{125}$ neither is as low as what one might predict given the extremely small likelihood of acquittal at trial for these charges. ${ }^{126}$

Of course, mandatory minimum sentences may not defeat plea bargaining; instead, they may merely shift the parties' attention toward charge bargaining, in which one or more counts are dismissed (or never filed) in return for a defendant's guilty plea to other existing or newly filed charges. Here again, charge substance can catalyze or chill plea bargaining. Crimes vary in the extent to which they stand alone within a code or are ensconced among multiple related offenses. This variety is a function of crime content. Some crimes involve behavior that is closely connected to other offenses (such as gun crimes and drug offenses, or theft and possession of stolen property), while other courses of criminal conduct tend to implicate only a single crime, which must be charged on its own, or not at all. As discussed below, depending on the

Economics of Stigma: Why More Detection of Crime May Result in Less Stigmatization, 36 J. LEGAL STUD. 355, 355 (2007). For a robust discussion of stigma and its relationship to punishment, see W. David Ball, The Civil Case at the Heart of Criminal Procedure: In re Winship, Stigma, and the CivilCriminal Distinction, 38 AM. J. CRIM. L. 117, 146-48 (2011).

123. See Samantha L. Friel, Porn by Any Other Name? A Constitutional Alternative to Regulating "Victimless" Computer-Generated Child Pornography, 32 VAL. U. L. REV. 207, 226 (1997) ("The crime of possession of child pornography carries with it a social stigma that could very well shatter one's reputation in the community."); Anthony O'Rourke, The Political Economy of Criminal Procedure Litigation, 45 GA. L. REV. 721, 743-44 (2011) (observing that more stigma attaches to child-pornography crimes than to marijuana possession); see also Dan Levine, Suicides Follow Porn Crackdown, RECORDER, June 9, 2008, at A1 (discussing a spate of suicides among defendants against whom child-pornography cases had been filed).

124. Subdivision (a) of 18 U.S.C. $§ 2252$ prohibits the sale, transportation, distribution, receipt, or possession (provided a jurisdictional nexus is satisfied) of "visual depiction[s] . . [the production of which involves] the use of a minor engaging in sexually explicit conduct," where the depictions are of such conduct. 18 U.S.C. $§ 2252$ (a) (2006). Section $2252 \mathrm{~A}$ is similar, but "[t]he principal difference between 18 U.S.C. $\S \S 2252$ and $2252 \mathrm{~A}$ is that the former prohibits 'visual depictions' involving the use of an actual minor, while the latter includes computer-generated images." United States v. Coleman, 54 M.J. 869, 872 (A. Ct. Crim. App. 2001).

125. Whereas 4.4 percent of all counts in the AOUSC Database went to trial, only 3.5 percent of counts brought under 18 U.S.C. $\S 2252$ (a) or 18 U.S.C. $\S 2252$ A were resolved this way. AOUSC Database, supra note 2.

126. While the combined trial rate for these crimes is only 78 percent of the database average, their acquittal rates at trial are lower still. The acquittal percentage for these crimes, put together (11.5 percent) is just 54 percent of the database average. AOUSC Database, supra note 2. 
scenario, these crime clusters can be either conducive or inhospitable to plea bargaining. Furthermore, where a crime falls within a constellation of related offenses with respect to its punishment terms will affect its encouragement of and disposition within these deals.

The connections, if any, that exist between a crime and other offenses matter because of their effect upon initial charging practices (which can prompt plea negotiations) and the existence and attractiveness of plausible plea deals. Crime "clusters" may facilitate plea arrangements by inviting prosecutors to allege charge combinations that are conducive to bargaining. If a crime tends to overlap with other offenses, such that a defendant's course of conduct implicates multiple different crimes, prosecutors may be in a position to charge all of the connected offenses. ${ }^{127}$ Doing so can encourage a defendant to enter into plea talks if the allegation of multiple crimes either increases the likelihood of conviction or threatens greater punishment upon conviction. ${ }^{128}$ At the same time, the prosecution might not have an equivalent, offsetting desire to secure convictions upon all of the charges, particularly if some of the counts are in some way ancillary to the gist of the defendant's misconduct. ${ }^{129}$ The prosecutor may be willing to jettison these surplus charges, if doing so induces a plea to the central allegations in the case.

Elsewhere, however, tight bonds among related offenses can have the opposite effect, chilling plea negotiations and pushing cases toward trial. If even one charged offense among several is susceptible to trial, the parties might decide to try all of the other charges as well; since a trial will take place anyway, the parties may perceive the incremental cost of trying the additional counts as relatively low. This dynamic can arise when the charge that draws others to trial both threatens significant irreducible punishment and represents the crux of the state's case against the defendant. Under these circumstances, this "immovable" count is relatively unlikely to become the subject of bargaining. When this situation arises, charges that normally would produce plea bargains are effectively dragged to trial by other offenses. Furthermore, charge-stacking may add to the complexity of a criminal case and, by doing so, prevent the parties from agreeing upon a disposition by introducing disagreement as to likely outcomes.

The positioning of a crime relative to related offenses can affect plea bargaining as much as its proximity to these crimes will. All else being equal, a crime is more susceptible to charge bargaining when it claims attractive "landing points" for these deals. These "landing points" consist of offenses that carry a gravamen similar to that of the bargained-down crime, but with slightly

127. STUNTZ, supra note 55, at 263.

128. Id.

129. See Graham, supra note 59, at 693 (discussing how crimes such as hostage-taking (18 U.S.C. § 1203) and use of fire or explosives in the commission of a federal felony (18 U.S.C. § 844(h)) are often dismissed pursuant to plea bargains). 
less severe sentencing consequences. ${ }^{130}$ It follows that within any given cluster of related offenses, the more serious crimes that carry harsher punishment terms normally will possess more charge-bargain options than are available when the prosecution charges one of the less severe crimes within the grouping. ${ }^{131}$

From the text above, one might conclude that crimes tend to produce more, and more consistently framed, guilty pleas when they are simple to prove, alleged with significant frequency, and have "stakes" as to which both the prosecution and the defense can obtain significant value from a plea, relative to trial. In essence, the more a crime can be commoditized, the more susceptible it will be to the entry of guilty pleas. The next Part of this Article seeks to put flesh on the bones of this hypothesis by reviewing several years' worth of federal charging and case termination data.

III.

\section{Federal DAta on Plea Bargaining ANd Trials}

The Administrative Office of the United States Courts (AOUSC) collects a wealth of information regarding each criminal case that terminates in federal district court. ${ }^{132}$ One series of datasets, released annually, includes the judicial district in which each prosecution occurred, the five "most serious" charges filed as to each defendant (as determined by the "base offense level" assigned to the crime under the Federal Sentencing Guidelines ${ }^{133}$ ), the five "most serious" charges at the time of case termination, the manner in which these charges were resolved (e.g., dismissal by the prosecution, guilty plea, or conviction or acquittal at trial ${ }^{134}$ ), the sentence issued by the court, and related information. ${ }^{135}$

130. Wright \& Engen, The Effects of Depth and Distance in a Criminal Code on Charging, Sentencing, and Prosecutor Power, supra note 19, at 1953-54. For a discussion of how prosecutors and defense attorneys locate and agree upon plausible landing points, see Sudnow, supra note 104, at 258-59, 262-64.

131. Wright \& Engen, The Effects of Depth and Distance in a Criminal Code on Charging, Sentencing, and Prosecutor Power, supra note 19, at 1953-55.

132. AOUSC Database, supra note 2.

133. The "base offense level" represents the starting point for sentencing calculations under the Federal Sentencing Guidelines, with higher base offense levels translating into lengthier Guidelines-prescribed advisory terms. ROGER W. HAINES JR. ET AL., FEDERAL SEnTENCING GUIDELINES HANDBOOK 1305 (2010).

134. The principal disposition codes used by the AOUSC are: 1 (dismissal), 2 (acquittal after a bench trial), 3 (acquittal after a jury trial), 4 (guilty plea), 5 (nolo contendere plea), 8 (conviction after a bench trial), 9 (conviction after a jury trial), A (nolle prosequi), B (pretrial diversion), $\mathrm{C}$ (mistrial), and D (dismissed without prejudice). E.g., INTER-Univ. CONSORTIUM FOR POLITICAL AND SOC. RESEARCh, Federal Justice Statistics Program: DefEndants in Federal Criminal CASES in DisTRICT COURT-TERMINATED, 2007 [UNITED STATES] 144 (2008).

135. As to each record, the dataset relates 177 fields of information. For purposes of this Article, the most important of these fields are DISTRICT, which identifies the judicial district in which a case was filed; FLINDEX1, FLINDEX2, FLINDEX3, FLINDEX4, and FLINDEX5, which relate 
The discussion below draws upon these records to explore the connections between charge substance and plea-bargaining and trial rates and outcomes. Specifically, the text will consider data regarding criminal cases that terminated in federal district court between October 1, 2002, and September 30, 2009. ${ }^{136}$ This information comes from AOUSC datasets compiled for FY2003 (October 1, 2002, to September 30, 2003) through FY2009 (October 1, 2008, to September 30, 2009). ${ }^{137}$ While these datasets are far from perfect-humans inputted the data, and humans make mistakes - they do provide a rough guide to the utilization of specific federal crimes. ${ }^{138}$

This review will begin with some aggregate information concerning the records in the database and summary data regarding plea bargaining, trial frequency, and trial outcomes. The analysis then will turn to a review of specific crimes with extremely high and low charge-bargain, trial, and acquittal rates. As will be shown, offenses perched at these extremes tend to share certain characteristics. These patterns hint at the effects that charge content may have on plea bargaining and trials.

\section{A. Basic Information}

The dataset compiled from the AOUSC material consists of 623,430 records in all. ${ }^{139}$ As contained in the database, each record relates to a single defendant in a single federal case, ${ }^{140}$ such that one case that involves multiple

the codes assigned to the five "most serious" initial charges in a case (with these codes typically taking the form of the title and section of the United States Code that relates the offense, as well as additional identifying elements in situations where a code section describes more than one crime); TRINDEX1, TRINDEX2, TRINDEX3, TRINDEX4, and TRINDEX5, which relate the codes assigned to the five "most serious" charges at the time of case termination; DISP1, DISP2, DISP3, DISP4, and DISP5, which relate the disposition of the five "most serious" crimes; PRISTOT, which relates the total prison time imposed upon each defendant; TTSECMO, which relates the title and section of the United States Code of the most serious terminating offense in the case; and FILEINDEX, which relates which, among the initial charges, represented the most serious charging offense.

136. Earlier datasets (e.g., for FY2000, FY2001, and FY2002) in the same Bureau of Justice Statistics/AOUSC series do not provide complete information regarding case outcomes, and thus were not included within the study.

137. AOUSC Database, supra note 2.

138. Upon consulting online court documents (as posted on the Public Access to Court Electronic Records (PACER) service) that correspond to particular cases found within the database, the author has perceived some mistaken descriptions of counts and count outcomes within the AOUSC data. Given the volume of the data within the database, it would be surprising if some such errors did not exist. Accordingly, the reader should take the specific figures provided herein, as drawn from the AOUSC data, with a grain of salt. These totals appear to be, at a minimum, directionally correct, and may be relied upon insofar as they speak to basic tendencies or trends (for example, a particular offense's general susceptibility to plea bargaining). Yet there is every possibility that each figure incorporates at least a few inputting gaffes, such that the specific totals and percentages presented herein may be somewhat higher, or lower, than the "true" numbers.

139. AOUSC Database, supra note 2.

140. Since the AOUSC Database relates only the charging and disposition of federal offenses, it does not necessarily reveal the plea-bargaining patterns that surround "comparable" state crimes. In some instances, the state analogue(s), if any, to a federal crime may be subject to forces and 
defendants may entail several records. For convenience, however, the text below will refer to each record as a separate "case."

Of the 623,430 cases contained within the database, 538,085 involve at least one count that was resolved via a guilty or no-contest plea. ${ }^{141}$ Meanwhile, 25,190 cases include at least one count that was resolved via a trial verdict. ${ }^{142}$ (In all, the database relates the outcome of 1,231,640 terminated counts, or charges. ${ }^{143}$ ) Overall, approximately 21 percent of counts tried to a verdict ${ }^{144}$ yielded acquittals, leaving an overall conviction rate of 79 percent. ${ }^{145}$ The overall acquittal rate was skewed slightly upward by a large number of trials of miscellaneous vehicle-code infractions that occurred on federal property. These trials often resulted in acquittals. ${ }^{146}$ If these cases are removed from the database, the acquittal rate drops to just above 20 percent of all counts. ${ }^{147}$

The roster of federal offenses is too extensive to assess the pleading and trial practices that surround each and every crime. Instead, the text below will focus on specific offenses, and in particular, those that lie at the extremes of the plea-bargaining and trial data.

\section{B. Plea Bargaining}

The AOUSC Database does not readily permit inquiries into simple sentence bargaining, since it does not include information (such as each

circumstances similar to those that prompt or deter plea bargaining in federal court. Elsewhere, seemingly analogous state and federal crimes may lead to quite different plea-bargaining practices, as may occur when the pertinent code structures and sentencing provisions diverge markedly.

141. AOUSC Database, supra note 2.

142. Id.

143. Id. Each federal crime has been assigned an identification code by the AOUSC. A list of these codes, as made available through the website for the United States District Court for the Western District of Pennsylvania, can be found at http://www.pawd.uscourts.gov/Documents/Forms/Criminal $\% 20$ Citation\%20Manual.pdf. The total number of counts in the database does not include every charge that was alleged and resolved in a criminal case over the studied period. Each case within the database relates only the five "most serious" charges at the time of original filing, and at case termination. Thus, to the extent that a criminal case alleged a sixth, seventh, or higher count, the dataset does not necessarily capture this information. Though a gap, only a small percentage of federal cases involve more than five counts. The truncation therefore has only a modest effect on the overall results-though it may have a more substantial impact on data relating to those crimes, such as wire fraud and mail fraud, that are sometimes alleged in bulk.

144. AOUSC Database, supra note 2 . The very few counts that reported a guilty or not-guilty verdict on an insanity plea were disregarded for purposes of determining conviction rates.

145. Id. This acquittal-rate figure likely understates defendants' overall trial "success" on a count-by-count basis. The AOUSC does not assign a distinct code to count dismissals that occur in the course of trial, as opposed to dismissals that occur at an earlier point in the proceedings. Thus, for purposes of calculating acquittal rates, the author simply summed not-guilty verdicts issued by juries and judges, and divided this total by the sum of jury and bench acquittals and convictions. To the extent that mid-trial dismissals also represent defense "wins," the acquittal figures do not capture these victories.

146. Id. These charges were assigned the code 18:13-7220.M within the AOUSC Database, and had an acquittal rate of 64 percent over the studied time period. Id.

147. Id. 
defendant's criminal history, or the sentence enhancements or downward departures implicated in a particular case) that affect the sentencing calculations for defendants under the Federal Sentencing Guidelines. ${ }^{148}$ By relating the "most serious" charges at the time of filing and case termination, however, the data do allow for a study of charge bargaining in federal practice. $^{149}$

Here, the data indicate that federal prosecutors are quite willing to dismiss certain crimes pursuant to plea deals. ${ }^{150}$ Elsewhere, I have referred to crimes that are commonly jettisoned in plea bargaining as "charging crimes.",151 Including these crimes in a case can facilitate plea bargaining insofar as the charges threaten significant incremental punishment or an enhanced likelihood of conviction, yet are understood by all parties as being subject to negotiation.

One rough proxy for a given crime's status as a charging crime is to assess the frequency with which it relinquished its status as the most serious charging offense (referred to in the tables below as "MSCO") in a case pursuant to a guilty or no-contest plea. This measure of the "integrity rate" of an offense reflects the crime's susceptibility to dismissal as part of a plea bargain. The following are crimes with particularly low integrity rates over the FY2003-FY2009 span:

148. For roughly the latter two-thirds of the studied time period, the Sentencing Guidelines were not mandatory, such that a sentencing judge did not necessarily have to regard a nominal "most serious" offense as such. See United States v. Booker, 543 U.S. 220, 245 (2005).

149. The base offense level represents an imperfect guide to charge severity. The assignment of "most serious" status based on base offense level alone may be inadequate where, for example, large amounts of drugs or stolen money are involved. These amounts may substantially increase the assigned punishment above that associated with the "normal" base offense level for a crime. See U.S. SENTENCING GUIDELINES MANUAL, supra note 5, §§ 2B1.1(b)(1), 2D1.1(c) (relating the base offense levels associated with amounts of money purloined and various drug quantities, respectively).

150. Per Department of Justice policy in effect for much of the studied time period, as a general matter, "federal prosecutors must charge and pursue the most serious, readily provable offense or offenses that are supported by the facts of the case." Memorandum from Att'y Gen. John Ashcroft to All Fed. Prosecutors, Department Policy Concerning Charging Criminal Offenses, Disposition of Charges, and Sentencing (Sept. 22, 2003), available at http://www.justice.gov/opa/pr/2003/September/ 03_ag_516.htm.

151. Graham, supra note 59, at 686-95. 
TABLE 1: Federal felonies with low "integrity rates" FY2003-FY2009 $(100+\text { MSCO cases involving guilty/no contest pleas })^{152}$

\begin{tabular}{|c|c|c|c|c|}
\hline Crime & Description & $\begin{array}{l}\text { Total } \\
\text { MSCO } \\
\text { cases }\end{array}$ & $\begin{array}{l}\text { MSCO cases where } \\
\text { also most serious } \\
\text { terminating offense } \\
\text { (MSTO) }\end{array}$ & $\begin{array}{l}\text { Integrity } \\
\text { rate }\end{array}$ \\
\hline $\begin{array}{l}18 \text { U.S.C. } \\
\quad \S 1512(\mathrm{a})^{153}\end{array}$ & $\begin{array}{l}\text { Witness tampering by } \\
\text { force/threat of force }\end{array}$ & 210 & 73 & $34.8 \%$ \\
\hline $\begin{array}{l}18 \text { U.S.C. } \\
\S 1203^{154}\end{array}$ & Hostage taking & 336 & 134 & $39.9 \%$ \\
\hline $\begin{array}{l}18 \text { U.S.C. } \\
\qquad \S 844(\mathrm{~h})^{155}\end{array}$ & $\begin{array}{l}\text { Use of fire/explosives in a } \\
\text { federal felony }\end{array}$ & 321 & 131 & $40.8 \%$ \\
\hline $\begin{array}{l}18 \text { U.S.C. } \\
\S 924(\mathrm{j})^{156}\end{array}$ & $\begin{array}{l}\text { Violent crime/drugs/gun/ } \\
\text { death occurs }\end{array}$ & 188 & 79 & $42.0 \%$ \\
\hline
\end{tabular}

The crimes in this table have something in common: they tend to be supplemental or ancillary to the gravamen of most criminal cases in which they appear. ${ }^{157}$ Witness tampering (18 U.S.C. $§ 1512(a)$ ) presumes the existence of a pending, or potential, federal case. So does hostage taking (18 U.S.C. § 1203), and the use of firearms or explosives in the commission of another federal offense (18 U.S.C. $\S 844(\mathrm{~h}))$. This shared characteristic ensures that a prosecutor often will allege these charges alongside another crime that, in fact, represents the crux of the government's case. The supplemental charge and any added punishment (or likelihood of conviction) that it threatens will encourage the defendant to plead guilty to the "core" offense, in exchange for dismissal of the added count. Prosecutors, meanwhile, typically will be only too happy to propose and agree to this deal, since the dismissed count does not represent the

152. The table is derived from data in the AOUSC Database, supra note 2.

153. Section 1512(a) of Title 18 prohibits actual and attempted witness tampering by means of force or threats of force. United States v. Lester, 749 F.2d 1288, 1293 (9th Cir. 1984). The AOUSC uses a distinct code to identify those cases in which this tampering results in the death of a witness.

154. [W]hoever ... seizes or detains and threatens to kill, to injure, or to continue to detain another person in order to compel a third person or a governmental organization to do or abstain from doing any act as an explicit or implicit condition for the release of the person detained, or attempts or conspires to do so, shall be punished ....

18 U.S.C. § 1203(a) (2006).

155. Whoever "uses fire or an explosive to commit any felony which may be prosecuted in a court of the United States, or . . carries an explosive during the commission of any felony which may be prosecuted in a court of the United States" shall be sentenced to ten years imprisonment. 18 U.S.C. § 844(h) (2006).

156. A person who, in the course of a violation of subsection (c) [use of a firearm in the commission of a federal felony], causes the death of a person through the use of a firearm, shall-(1) if the killing is a murder (as defined in section 1111), be punished by death or by imprisonment for any term of years or for life; and (2) if the killing is manslaughter (as defined in section 1112), be punished as provided in that section.

18 U.S.C. $§ 924(j)(2006)$.

157. Graham, supra note 59, at 694. 
tent-pole of their case against the defendant. Instead, the charge to which the defendant enters a guilty plea typically carries sufficient punishment and expressive impact to satisfy the prosecution.

Other crimes may catalyze plea bargaining in a similar way, even though they less frequently represent the most serious charge in a case and therefore do not appear within the table above. It has been suggested, for example, that the enhancement for the use of a firearm in the commission of a federal felony, codified at 18 U.S.C. $\$ 924(\mathrm{c}),{ }^{158}$ often represents a "bargaining chip" in federal drug cases. ${ }^{159}$ The charge threatens significant additional punishment upon conviction, such that the defense will want to secure its dismissal prior to sentencing. But because the $\S 924$ (c) enhancement tends to be ancillary to the central thrust of a case, the argument goes, the prosecution frequently will agree to negotiate it away in exchange for a plea to other counts. The data provide some support for this supposition. Between FY2003 and FY2009, a total of $26,680 \S 924$ (c) charges were alleged in cases that resolved, in whole or in part, by a defendant's guilty or no-contest plea. ${ }^{160}$ Of these $\S 924(\mathrm{c})$ charges, fully 45 percent were dismissed either prior to, or as part of, the defendant's plea. ${ }^{161}$ Forty-five percent is a relatively high figure, ${ }^{162}$ particularly for a crime that carries a full consecutive sentence (such that its dismissal would not represent a pro forma act by the prosecution); by comparison, less than 40 percent of all counts within the database were dismissed in cases that terminated by plea. ${ }^{163}$

Meanwhile, the crimes that claimed the highest integrity rates-suggesting very few charge bargains that involved the dismissal of these

158. Section 924 (c) of Title 18 provides that a five-year (or greater, if additional facts are found) sentence enhancement is to be imposed upon

any person who, during and in relation to any crime of violence or drug trafficking crime (including a crime of violence or drug trafficking crime that provides for an enhanced punishment if committed by the use of a deadly or dangerous weapon or device) for which the person may be prosecuted in a court of the United States, uses or carries a firearm, or who, in furtherance of any such crime, possesses a firearm.

18 U.S.C. $\S 924(c)(2006)$.

159. BurEau OF JUSTICE StATISTICS, FEDERAL FirEARM OFFENDERS, 1992-98, at 6 (2000) (discussing the frequent dismissal of $\S 924$ (c) charges); Nagel \& Schulhofer, supra note 50, at 548-49, 551-52 (remarking on the dismissal of $\S 924$ (c) counts in certain types of cases).

160. AOUSC Database, supra note 2.

161. Id.

162. At the same time, a 45 percent dismissal rate pursuant to pleas is hardly extreme, or particularly telling. Fully 71.9 percent of hostage-taking counts (18 U.S.C. $§ 1203$ ) were dismissed in cases resolved by a guilty or no-contest plea, AOUSC Database, supra note 2, and several frequently alleged drug crimes had dismissal rates hovering around 50 percent, $i d$. Near the other end of the spectrum, counts under 8 U.S.C. $\S 1326$ were dismissed less than 10 percent of the time in pled matters. AOUSC Database, supra note 2.

163. Id. 
offenses-were misdemeanors. ${ }^{164}$ Among felonies, the crimes with the highest integrity rates included:

TABLE 2: Federal felonies with high "integrity rates" FY2003-FY2009 $\left(250+\right.$ MSCO cases involving guilty/no contest pleas) ${ }^{165}$

\begin{tabular}{|c|c|c|c|c|}
\hline Crime & Description & $\begin{array}{c}\text { Total MSCO } \\
\text { cases }\end{array}$ & $\begin{array}{l}\text { Total MSCO cases } \\
\text { where also MSTO }\end{array}$ & $\begin{array}{l}\text { Integrity } \\
\text { rate }\end{array}$ \\
\hline 18 U.S.C. $\$ 4$ & Misprision of a felony & 857 & 853 & $99.5 \%$ \\
\hline $\begin{array}{l}18 \text { U.S.C. } \\
\quad \S 751(a)^{166}\end{array}$ & Escape & 1564 & 1549 & $99.0 \%$ \\
\hline $\begin{array}{l}18 \text { U.S.C. } \\
\quad \S 2252(\mathrm{a})\end{array}$ & $\begin{array}{l}\text { Sale, distribution, or } \\
\text { possession of child } \\
\text { pornography }\end{array}$ & 4879 & 4815 & $98.7 \%$ \\
\hline $\begin{array}{l}8 \text { U.S.C. } \\
\S 1326^{167}\end{array}$ & $\begin{array}{l}\text { Reentry by a deported } \\
\text { alien }\end{array}$ & 85,779 & 83,984 & $97.9 \%$ \\
\hline $\begin{array}{l}18 \text { U.S.C. } \\
\quad \S 3146(a)^{168}\end{array}$ & Failure to appear & 462 & 450 & $97.4 \%$ \\
\hline $\begin{array}{l}18 \text { U.S.C. } \\
\quad \S 922(n)^{169}\end{array}$ & $\begin{array}{l}\text { Interstate transportation of } \\
\text { a firearm/felon }\end{array}$ & 1130 & 1099 & $97.3 \%$ \\
\hline
\end{tabular}

164. The following misdemeanors all claimed an integrity rate of at least 99.5 percent: 18 U.S.C. § 1028(a) (fraud with identification documents); 18 U.S.C. § 1703(b) (delay or destruction of mail); 18 U.S.C. $\$ 3615$ (failure to pay a fine); 26 U.S.C. $§ 7203$ (c) (willful failure to file a tax return); and 18 U.S.C. $\S 656$ (theft or embezzlement by a bank officer). AOUSC Database, supra note 2.

165. The table is derived from data in the AOUSC Database, supra note 2.

166. A conviction for escape under $\S 751$ (a) requires proof of three elements. The Government must show that the defendant made 1) an unauthorized departure or escape, 2) from custody of an institution where the prisoner is confined by direction of the Attorney General, 3) where the custody or confinement is by virtue either of arrest for a felony or conviction of any offense.

United States v. Taylor, 933 F.2d 307, 309 (5th Cir. 1991).

167. To the extent that the tables relate data involving 8 U.S.C. $\S 1326$, the figures presented represent the summed total of counts alleged under 8 U.S.C. $§ 1326,8$ U.S.C. $\S 1326(a)$, and 8 U.S.C. $\S 1326(\mathrm{~b})$, which were assigned separate codes within the AOUSC data. All three codes displayed similar tendencies.

168. Under 18 U.S.C. $§ 3146(a)$, a person who has been released by the court pending criminal proceedings yet who "fails to appear before a court as required by the conditions of release," or who "fails to surrender for service of sentence pursuant to a court order," is guilty of either a felony or a misdemeanor, depending on the circumstances. 18 U.S.C. § 3146(a) (2006). "To establish a violation of 18 U.S.C. § 3146, the government ordinarily must prove that the defendant (1) was released pursuant to that statute, (2) was required to appear in court, (3) knew that he was required to appear, (4) failed to appear as required, and (5) was willful in his failure to appear." Weaver v. United States, 37 F.3d 1411, 1412-13 (9th Cir. 1994) (citing United States v. McGill, 604 F.2d 1252, 1254 (9th Cir. 1979)).

169. It shall be unlawful for any person who is under indictment for a crime punishable by imprisonment for a term exceeding one year to ship or transport in interstate or foreign commerce any firearm or ammunition or receive any firearm or ammunition which has been shipped or transported in interstate or foreign commerce.

18 U.S.C. § 922(n) (2006). 
Just as the offenses with the lowest integrity rates share certain attributes, so do the crimes with the highest such rates. ${ }^{170}$ Namely, these crimes are among the easiest federal crimes to prove. The simplicity of proving reentry of a deported felon (8 U.S.C. § 1326) already has been discussed. An escape charge is similarly easy to establish: the defendant was in custody; then, she was not. ${ }^{171}$ Similarly, a charge alleging a failure to appear (18 U.S.C. $\S 3146(a)$ ) is virtually bulletproof for the prosecution, assuming that the defendant was previously advised of the need to show up in court (a matter typically capable of ready and virtually unassailable proof by resort to judicial minutes). ${ }^{172}$ With these offenses, defendants likely reason that a pretrial guilty plea, with credit for early acceptance of responsibility, offers as good an outcome as they can reasonably expect. Meanwhile, the felony with the highest "integrity rate"-misprision of a felony (18 U.S.C. § 4) -is a "pleading crime" that parties often agree upon as the basis of a plea deal, often even before the prosecution files charges. ${ }^{173}$

\section{Trials}

Just as some crimes are more conducive to charge bargains than others are, some offenses produce more trials than others do. Overall, only 4.4 percent of all charged counts within the dataset went to trial. ${ }^{174}$ Yet significant variation appears in trial rates across offenses. The following crimes proceeded to trial most often, relative to how often they were alleged:

170. See Graham, supra note 59, at 690-92 (describing some of the characteristics of crimes with high "integrity rates"). At the same time, the appearance of a crime within this table does not preclude the possibility of plea bargaining along other dimensions. The parties in drug cases can bargain over the quantities of drugs for which a defendant will be held responsible; the defense and prosecution in a child pornography case may negotiate over the number of images that the defendant possessed; etc. Likewise, in cases where the defendant committed the same crime on multiple occasions, prosecutors may agree to dismiss a second, third, or additional count that alleges the same offense as the "lead" charge. See Nagel \& Schulhofer, supra note 50, at 548. In each of these scenarios, one must engage in a more sensitive analysis than the mere documentation of integrity rates to understand the nature of the bargaining process.

171. Escape "does not require that a defendant have a specific intent to escape; all the prosecution must show is that the defendant knew that his actions would result in his absence from confinement without permission." Taylor, 933 F.2d at 310 (citing United States v. Bailey, 444 U.S. 394 (1980)).

172. Weaver, 37 F.3d at 1412-13.

173. See Graham, supra note 59, at 697-98 (discussing "pleading crimes").

174. AOUSC Database, supra note 2. Counts that were dismissed by the prosecution at trial are not assigned a code distinct from the "generic" code for count dismissal, meaning that this 4.4 percent figure-which does not include dismissed counts-may slightly underestimate the total number of tried counts. 
TABLE 3: Highest percentage of counts tried, federal felonies FY2003FY2009 (200+ counts) $)^{175}$

\begin{tabular}{|c|c|c|c|c|}
\hline Crime & Description & $\begin{array}{l}\text { Total } \\
\text { terminating } \\
\text { counts }\end{array}$ & $\begin{array}{c}\text { Total } \\
\text { tried } \\
\text { counts }\end{array}$ & $\begin{array}{l}\text { Percentage of } \\
\text { tried counts }\end{array}$ \\
\hline 18 U.S.C. $\S 242$ & Deprivation of civil rights & 481 & 145 & $30.1 \%$ \\
\hline 26 U.S.C. $\S 7212(a)^{176}$ & $\begin{array}{l}\text { Corrupt/forcible interference/ } \\
\text { IRS }\end{array}$ & 273 & 66 & $24.2 \%$ \\
\hline 18 U.S.C. $\S 241^{177}$ & $\begin{array}{l}\text { Conspiracy against the rights of } \\
\text { citizens }\end{array}$ & 406 & 93 & $22.9 \%$ \\
\hline 18 U.S.C. $\S 924(j)$ & $\begin{array}{l}\text { Violent crime/drugs/firearm/ } \\
\text { death occurs }\end{array}$ & 395 & 89 & $22.5 \%$ \\
\hline $\begin{array}{l}18 \text { U.S.C. } \$ 1959 \\
(7474)^{178}\end{array}$ & Racketeering/violent crimes & 227 & 50 & $22.0 \%$ \\
\hline $\begin{array}{l}18 \text { U.S.C. § } 1958 \\
(7471)^{179}\end{array}$ & Racketeering/murder & 427 & 92 & $21.5 \%$ \\
\hline
\end{tabular}

175. The information in this table is derived from data in the AOUSC Database, supra note 2.

176. This statute, part of the Internal Revenue Code, makes it a federal offense to corruptly or by force or threats of force (including any threatening letter or communication) endeavor[] to intimidate or impede any officer or employee of the United States acting in an official capacity under this title, or in any other way corruptly or by force or threats of force (including any threatening letter or communication) obstruct[] or impede[], or endeavor[] to obstruct or impede, the due administration of this title.

26 U.S.C. § 7212(a) (2006).

177. Under this statute, a felony has been committed "[i]f two or more persons conspire to injure, oppress, threaten, or intimidate any person in any State, Territory, Commonwealth, Possession, or District in the free exercise or enjoyment of any right or privilege secured to him by the Constitution or laws of the United States, or because of his having so exercised the same," or "[i]f two or more persons go in disguise on the highway, or on the premises of another, with intent to prevent or hinder his free exercise or enjoyment of any right or privilege so secured." 18 U.S.C. § 241 (2006).

178. Section 1959 of Title 18 of the United States Code relates a felony offense when someone,

as consideration for the receipt of, or as consideration for a promise or agreement to pay, anything of pecuniary value from an enterprise engaged in racketeering activity, or for the purpose of gaining entrance to or maintaining or increasing position in an enterprise engaged in racketeering activity, murders, kidnaps, maims, assaults with a dangerous weapon, commits assault resulting in serious bodily injury upon, or threatens to commit a crime of violence against any individual in violation of the laws of any State or the United States, or attempts or conspires so to do.

18 U.S.C. § 1959(a) (2006). The code in parentheses refers to the AOUSC Codebook descriptive references, see supra, note 143 .

179. Under 18 U.S.C. $§ 1958(a)$,

Whoever travels in or causes another (including the intended victim) to travel in interstate or foreign commerce, or uses or causes another (including the intended victim) to use the mail or any facility of interstate or foreign commerce, with intent that a murder be committed in violation of the laws of any State or the United States as consideration for the receipt of, or as consideration for a promise or agreement to pay, anything of pecuniary value, or who conspires to do so, shall be fined under this title or imprisoned for not more than ten years, or both; and if personal injury results, shall be fined under this title or imprisoned for not more than twenty years, or both; and if death results, shall be punished by death or life imprisonment, or shall be fined not more than $\$ 250,000$, or both.

18 U.S.C. $\S 1958$ (2006). The code in parentheses refers to the AOUSC Codebook descriptive references, see supra, note 143 . 


\begin{tabular}{llccc}
\hline \hline Crime & Description & $\begin{array}{c}\text { Total } \\
\text { terminating } \\
\text { counts }\end{array}$ & $\begin{array}{c}\text { Total } \\
\text { tried } \\
\text { counts }\end{array}$ & $\begin{array}{c}\text { Percentage of } \\
\text { tried counts }\end{array}$ \\
\hline 18 U.S.C. $\S 666(\mathrm{c})^{180}$ & $\begin{array}{c}\text { Embezzlement involving } \\
\text { federal programs }\end{array}$ & 434 & 87 & $20 \%$ \\
\hline \hline
\end{tabular}

Again, several of these crimes have something in common: they carry extremely high stakes for both the prosecution and the defense-suggesting a large "nonnegotiable" component in each prosecution. Indeed, several of these crimes are punishable by death. ${ }^{181}$ Somewhat similarly, while the obstruction of justice offenses described at 18 U.S.C. § 1512(a) through (c) narrowly missed inclusion on the list of most commonly tried crimes, ${ }^{182}$ their high trial rates underscore how the prosecution has a strong incentive to spotlight these witness-intimidation and falsified-evidence cases through robust prosecution, while the defendants in these matters already have signaled their intention to fight the charges against them with all means at their disposal. ${ }^{183}$

For purposes of comparison, the following federal felonies ${ }^{184}$ go to trial the least often:

180. This code denotes one of the embezzlement offenses described at 18 U.S.C. $\S 666$ (2006), which makes it a federal crime to embezzle $\$ 5000$ or more from an institution that receives at least $\$ 10,000$ a year in federal benefits.

181. E.g., 18 U.S.C. § 924(j) (2006) (providing, through a cross-reference to 18 U.S.C. § 1111, for death as a possible punishment for murder through use of a firearm in the commission of a federal drug-trafficking crime or federal crime of violence); 18 U.S.C. § 1512(a)(3)(A) (2006) (providing, also through a cross-reference to 18 U.S.C. $\$ 1111$, for death as a possible punishment for the killing of a witness); 18 U.S.C. § 1958(a) (2006) (providing for punishment by death or life imprisonment if death results from a murder-for-hire scheme that involves interstate commerce).

182. The composite trial rate for the offenses related at 18 U.S.C. $\S 1512$ (a) through (c) was 19.3 percent. AOUSC Database, supra note 2.

183. The offense related at 26 U.S.C. $§ 7212$ (a) is similarly situated.

184. The absolute lowest trial rate among all commonly charged federal crimes belongs to 18 U.S.C. § 1028(a) (fraud with identification documents), when charged as a misdemeanor, as to which only 4 out of 4989 terminated counts were resolved by trial. 
TABLE 4: Lowest percentage of counts tried, federal felonies FY2003FY2009 (200+ counts $)^{185}$

\begin{tabular}{llccc}
\hline \hline Crime & Description & $\begin{array}{c}\text { Total } \\
\text { terminating } \\
\text { counts }\end{array}$ & $\begin{array}{c}\text { Total } \\
\text { tried } \\
\text { counts }\end{array}$ & $\begin{array}{c}\text { Percentage } \\
\text { of tried } \\
\text { counts }\end{array}$ \\
\hline 18 U.S.C. $\S 4^{186}$ & Misprision of a felony & 3672 & 14 & $0.4 \%$ \\
8 U.S.C. $\$ 1325^{187}$ & Improper entry by an alien & 14,852 & 75 & $0.5 \%$ \\
8 U.S.C. $\S 1326$ & Reentry of a deported alien & 98,201 & 534 & $0.5 \%$ \\
18 U.S.C. $\S 1543^{188}$ & Forgery or use of a forged passport & 1567 & 11 & $0.7 \%$ \\
\hline \hline
\end{tabular}

Unlike the most commonly tried crimes, these offenses tend to be minor and easily commoditized, such that a "going rate" for a guilty plea will coalesce around them in short order. The appearance on this list of 18 U.S.C. $\S 4$ and 8 U.S.C. $\S 1326$, in particular, comes as little surprise. As mentioned before, misprision of a felony is invoked in connection with prearranged plea bargains; with 8 U.S.C. $\S 1326$ (as well as 8 U.S.C. $\S 1325$ ), convictions are so easy to obtain that the defense receives little to no benefit from taking a case to trial, relative to the early entry of a guilty plea.

\section{Trial Outcomes}

On its own, data concerning trial rates says little about the relationship between plea bargaining and the ease or difficulty of proving a charge. To establish such a connection, one also must consider trial outcomes. The following are the federal felonies that the AOUSC data indicate have the highest acquittal rates at trial:

185. The table is derived from data in the AOUSC Database, supra note 2.

186. As previously related, the low trial rate for 18 U.S.C. $\S 4$ (misprision of a felony) owes to its status as a pleading crime - an offense that the parties in a variety of cases in which other, more serious crimes either were or might have been charged agree upon as a means of resolving these cases by way of a guilty or no-contest plea. See supra text accompanying note 173 . Tellingly, there were 3376 reported convictions among the 3672 terminating counts ascribed to 18 U.S.C. $§ 4$ within the database.

187. Any alien who (1) enters or attempts to enter the United States at any time or place other than as designated by immigration officers, or (2) eludes examination or inspection by immigration officers, or (3) attempts to enter or obtains entry to the United States by a willfully false or misleading representation or the willful concealment of a material fact is guilty of a misdemeanor (for a first offense); subsequent convictions can lead to imprisonment for up to two years. 8 U.S.C. $§ 1325$ (2006).

188. This offense applies to

[w] hoever falsely makes, forges, counterfeits, mutilates, or alters any passport or instrument purporting to be a passport, with intent that the same may be used; or [w]hoever willfully and knowingly uses, or attempts to use, or furnishes to another for use any such false, forged, counterfeited, mutilated, or altered passport or instrument purporting to be a passport, or any passport validly issued which has become void by the occurrence of any condition therein prescribed invalidating the same.

18 U.S.C. $\S 1543$ (2006). 
TABLE 5: High acquittal rates, federal felonies, 75+ tried counts FY2003-FY2009 ${ }^{189}$

\begin{tabular}{|c|c|c|c|c|}
\hline Crime & Description & $\begin{array}{l}\text { Tried } \\
\text { counts }\end{array}$ & $\begin{array}{l}\text { Count } \\
\text { acquittals }\end{array}$ & $\begin{array}{c}\text { Acquittal } \\
\text { percentage }\end{array}$ \\
\hline 18 U.S.C. $\S 242$ & Deprivation of civil rights & 145 & 80 & $55.2 \%$ \\
\hline 18 U.S.C. $§ 241$ & Conspiracy to deprive of civil rights & 93 & 44 & $47.3 \%$ \\
\hline $\begin{array}{l}18 \text { U.S.C. } \\
\quad \S 113(\mathrm{a})(3)^{190}\end{array}$ & Assault with a dangerous weapon & 123 & 57 & $46.3 \%$ \\
\hline $\begin{array}{l}21 \text { U.S.C. } \S 844^{191} \\
\text { (marijuana) }\end{array}$ & Possession of marijuana & 97 & 44 & $45.4 \%$ \\
\hline $\begin{array}{l}18 \text { U.S.C. } \\
\S 113(\mathrm{a})(6)^{192}\end{array}$ & $\begin{array}{l}\text { Assault resulting in serious bodily } \\
\text { injury }\end{array}$ & 82 & 35 & $42.7 \%$ \\
\hline $\begin{array}{l}18 \text { U.S.C. } \\
\quad \S 113(\mathrm{a})(1)^{193}\end{array}$ & Assault with intent to murder & 173 & 70 & $40.5 \%$ \\
\hline $\begin{array}{l}18 \text { U.S.C. } \\
\S 2241(\mathrm{a})^{194}\end{array}$ & Aggravated sexual abuse & 114 & 43 & $38.3 \%$ \\
\hline $\begin{array}{l}21 \text { U.S.C. } \S 952 \\
\text { (marijuana) }^{195}\end{array}$ & Importation of marijuana & 189 & 71 & $37.6 \%$ \\
\hline
\end{tabular}

189. The table is derived from data in the AOUSC Database, supra note 2.

190. Section 113 of Title 18 of the United States Code concerns assaults committed within the territorial or maritime jurisdiction of the United States. Per subdivision (a)(3), whoever commits an "[a]ssault with a dangerous weapon, with intent to do bodily harm, and without just cause or excuse, [is punishable] by a fine under this title or imprisonment for not more than ten years, or both." 18 U.S.C. § 113(a)(3) (2006).

191. It shall be unlawful for any person knowingly or intentionally to possess a controlled substance unless such substance was obtained directly, or pursuant to a valid prescription or order, from a practitioner, while acting in the course of his professional practice, or except as otherwise authorized by this subchapter or subchapter II of this chapter.

21 U.S.C. § 844(a) (2006). The code above describes only the possession of marijuana.

192. An "[a]ssault resulting in serious bodily injury [is punishable] by a fine under this title or imprisonment for not more than ten years, or both." 18 U.S.C. § 113(a)(6) (2006).

193. An "[a]ssault with intent to commit murder [is punishable] by imprisonment for not more than twenty years." 18 U.S.C. § 113(a)(1) (2006).

194. This law, which essentially relates the crime of aggravated rape, provides that one who, within the maritime or territorial jurisdiction of the United States or while in federal custody

knowingly causes another person to engage in a sexual act - (1) by using force against that other person; or (2) by threatening or placing that other person in fear that any person will be subjected to death, serious bodily injury, or kidnapping; or attempts to do so, shall be fined under this title, imprisoned for any term of years or life, or both.

18 U.S.C. $\S 2241$ (a) (2006).

195. "It shall be unlawful to import into the customs territory of the United States from any place outside thereof (but within the United States), or to import into the United States from any place outside thereof" a variety of controlled substances, narcotics, or ephedrine, pseudoephedrine, or phenylpropanolamine. 21 U.S.C. $\S 952$ (a) (2006). The code above refers only to the importation of marijuana, which is classified as a controlled substance under federal law. 21 C.F.R. § 1308.11 (2011). For unknown reasons, the AOUSC Database utilizes multiple codes for marijuana importation; the figure above represents a composite of these codes. As will be discussed infra, regardless of the code that is used to describe them, these charges exhibit similar characteristics. 


\begin{tabular}{llccc}
\hline \hline Crime & Description & $\begin{array}{c}\text { Tried } \\
\text { counts }\end{array}$ & $\begin{array}{c}\text { Count } \\
\text { acquittals }\end{array}$ & $\begin{array}{c}\text { Acquittal } \\
\text { percentage }\end{array}$ \\
\hline 18 U.S.C. § 666(c) & $\begin{array}{c}\text { Embezzlement involving federal } \\
\text { programs }\end{array}$ & 87 & 31 & $35.6 \%$ \\
$\begin{array}{c}\text { 18 U.S.C. } \\
\text { § 1512(c) })^{196}\end{array}$ & $\begin{array}{c}\text { Obstruction/presentation of a } \\
\text { falsified document to the court }\end{array}$ & 84 & 31 & $36.9 \%$ \\
\hline \hline
\end{tabular}

The following are the federal felonies with the lowest acquittal rates:

\section{TABLE 6: Low acquittal rates, federal felonies, 75+ tried counts FY2003-FY2009 ${ }^{197}$}

\begin{tabular}{|c|c|c|c|c|}
\hline Code section & Offense description & $\begin{array}{l}\text { Tried } \\
\text { counts }\end{array}$ & Acquittals & $\begin{array}{c}\text { Acquittal } \\
\text { percentage }\end{array}$ \\
\hline $\begin{array}{l}26 \text { U.S.C. } \\
\quad \S 7203(\mathrm{~d})^{198}\end{array}$ & Willful failure to file a tax return (felony) & 91 & 4 & $4.4 \%$ \\
\hline $\begin{array}{l}18 \text { U.S.C. } \\
\quad \S 924(\mathrm{j})\end{array}$ & $\begin{array}{l}\text { Violent crime/drugs/machine gun/where } \\
\text { death occurs }\end{array}$ & 89 & 5 & $5.6 \%$ \\
\hline $\begin{array}{l}21 \text { U.S.C. } \\
\quad \S 841(\mathrm{~g})^{199}\end{array}$ & $\begin{array}{l}\text { Possession of a controlled substance } \\
\text { (date-rape drugs) with intent to } \\
\text { distribute }\end{array}$ & 96 & 7 & $7.3 \%$ \\
\hline
\end{tabular}

196. Whoever corruptly - (1) alters, destroys, mutilates, or conceals a record, document, or other object, or attempts to do so, with the intent to impair the object's integrity or availability for use in an official proceeding; or (2) otherwise obstructs, influences, or impedes any official proceeding, or attempts to do so, shall be fined under this title or imprisoned not more than 20 years, or both.

18 U.S.C. $\S 1512$ (c) (2006). The preceding provisions of 18 U.S.C. $\S 1512$, which concern witness intimidation through force or violence (or the threat thereof), also featured high acquittal rates. The acquittal rate for charges under 18 U.S.C. § 1512 (a) stood at 23.5 percent; the rate for charges under $\S$ 1512(b), at 34.4 percent. AOUSC Database, supra note 2.

197. The table is derived from data in the AOUSC Database, supra note 2.

198. Under this section of the Internal Revenue Code, failure to file a form relating a cash transaction of $\$ 10,000$ or more in the course of business is punishable as a felony. This crime is sometimes implicated in complex cases with a money-laundering component. See Bickham-LincolnMercury Inc. v. United States, 168 F.3d 790, 793 (5th Cir. 1999) (describing the nature of reporting requirement implicated by $\S 7203$ 's felony provision).

199. Subdivision (g) of 21 U.S.C. $\S 841$ applies specifically to sales of "date-rape" drugs over the Internet. Under subdivision $(\mathrm{g})(1)$,

[w] hoever knowingly uses the Internet to distribute a date rape drug to any person, knowing or with reasonable cause to believe that-(A) the drug would be used in the commission of criminal sexual conduct; or (B) the person is not an authorized purchaser; shall be fined under this subchapter or imprisoned not more than 20 years, or both.

21 U.S.C. $\S 841(\mathrm{~g})(1)(2006)$. 


\begin{tabular}{|c|c|c|c|c|}
\hline Code section & Offense description & $\begin{array}{l}\text { Tried } \\
\text { counts }\end{array}$ & Acquittals & $\begin{array}{l}\text { Acquittal } \\
\text { percentage }\end{array}$ \\
\hline $\begin{array}{l}18 \text { U.S.C. } \\
\S 2251^{200}\end{array}$ & Sexual exploitation of children & 106 & 9 & $8.5 \%$ \\
\hline $\begin{array}{l}18 \text { U.S.C. } \\
\S 2113(\mathrm{~d})^{201}\end{array}$ & $\begin{array}{l}\text { Bank robbery/theft, Assault with a deadly } \\
\text { weapon }\end{array}$ & 135 & 12 & $8.9 \%$ \\
\hline $\begin{array}{l}18 \text { U.S.C. } \\
\S 876^{202}\end{array}$ & Mailing threats, ransom letters, etc. & 86 & 8 & $9.3 \%$ \\
\hline $\begin{array}{l}8 \text { U.S.C. } \\
\S 1326\end{array}$ & Reentry of a deported alien & 534 & 51 & $9.6 \%$ \\
\hline $\begin{array}{l}18 \text { U.S.C. } \\
\S 2252(\mathrm{a})\end{array}$ & $\begin{array}{l}\text { Sale, distribution, or possession of child } \\
\text { pornography }\end{array}$ & 379 & 39 & $10.3 \%$ \\
\hline $\begin{array}{l}21 \text { U.S.C. } \\
\S 848^{203}\end{array}$ & Continuing criminal enterprise & 117 & 13 & $11.1 \%$ \\
\hline
\end{tabular}

200. This crime applies to

[a]ny person who employs, uses, persuades, induces, entices, or coerces any minor to engage in, or who has a minor assist any other person to engage in, or who transports any minor in interstate or foreign commerce, or in any Territory or Possession of the United States, with the intent that such minor engage in, any sexually explicit conduct for the purpose of producing any visual depiction of such conduct or for the purpose of transmitting a live visual depiction of such conduct, assuming that a jurisdictional prerequisite is satisfied.

18 U.S.C. § 2251(a) (2008).

201. Section 2113, subdivision (a) of Title 18 relates two somewhat distinct crimes. The first is essentially bank robbery; this crime applies to one who "by force and violence, or by intimidation," or by extortion, takes or attempts to take property, money, or anything else of value from a bank or similar financial institution. The second of these offenses amounts to bank burglary; it creates the felony crime of entering or attempting to enter a bank or like establishment with the intent to commit therein any felony affecting the institution, or larceny. 18 U.S.C. $\S 2113$ (a) (2006). Subdivision (b) of the statute makes it a federal crime to "take[] and carr[y] away, with intent to steal or purloin, any property or money or any other thing of value... belonging to, or in the care, custody, control, management, or possession of any bank, credit union, or any savings and loan association." 18 U.S.C. $\S 2113$ (b). Subdivision (d) of this statute, meanwhile, provides that "[w]hoever, in committing, or in attempting to commit, any offense defined in subsections (a) and (b) of this section, assaults any person, or puts in jeopardy the life of any person by the use of a dangerous weapon or device, shall be fined under this title or imprisoned not more than twenty-five years, or both." 18 U.S.C. § 2113(d).

202. Section 876 of Title 18 makes it a federal crime to use the mail to send ransom letters or threatening communications. What is likely the most commonly invoked provision of this statute relates,

[w]hoever knowingly so deposits [in any post office or authorized depository for mail matter] or causes to be delivered [by the Postal Service according to the direction thereon] ... any communications with or without a name or designating mark subscribed thereto, addressed to any other person and containing ... any threat to injure the person of the addressee or of another, shall be fined under this title or imprisoned not more than five years, or both.

18 U.S.C. $\$ 876$ (2006).

203. To prove a violation of 21 U.S.C. $\S 848$, the government must establish that

(1) the defendant committed a felony violation of the federal narcotics laws, (2) the violation was part of a continuing series of violations, (3) the series of offenses occurred in concert with five or more persons, (4) the defendant was an organizer, supervisor, or manager, and (5) the defendant obtained substantial income or resources from the series of violations.

United States v. Soto-Beníquez, 356 F.3d 1, 25 (1st Cir. 2003). 
Particularly when mapped against trial rates, this information indicates that substantial variation exists among crimes in their conduciveness to guilty verdicts at trial. ${ }^{204}$ The data also help plea-bargaining dynamics come into better focus. Several crimes with particularly high acquittal rates, such that defense attorneys likely appreciate a substantial chance of a positive result at trial, also have high trial rates. Specifically, the most frequently tried crime, 18 U.S.C. $\S 242$, also happens to be the offense with the highest acquittal rate at trial. The third most frequently tried crime, 18 U.S.C. $\S 241$, claims the second-highest acquittal rate. Embezzlement from a federal program (18 U.S.C. $\S 666(c))$ also appears on both the list of most commonly tried crimes and the roster of crimes that most often lead to acquittal at trial. Presentation of a falsified document to a court (18 U.S.C. $§ 1512(\mathrm{c})$ ) and aggravated sexual abuse (18 U.S.C. $\S 2241(\mathrm{a})$ ), both of which appear on the latter list, fell just short of appearing on the list of most frequently tried charges. ${ }^{205}$ At the other extreme, the 8 U.S.C. $\S 1326$ series of offenses has among the highest conviction rates at trial, even accounting for the extremely low percentage of these cases that are put before a judge or jury. ${ }^{206}$ It seems doubtful that these overlaps represent mere coincidences. On the contrary, these results suggest that, at least under the right conditions, trial outcomes can have a substantial impact on trial rates and, by inference, on plea bargaining.

These results also underscore the importance of code substance, together with code structure, in pushing cases toward trial. Aggravated assault, such as the crimes specified by 18 U.S.C. $\S 113(\mathrm{a})$ and (c), can be difficult to prove. These cases often entail situations in which the prosecution's witnesses were distracted, drunk, or complicit in some wrongdoing connected to the charges (such as throwing the first punch in a fight). These concerns will lead prosecutors to reject many of these cases. Yet even in filed cases, the outcome may turn on the credibility of the prosecution's witnesses. Here, a jury's assessment of a witness might not be the same as the prosecutor's. This disconnect, which is inevitable across assault cases but cannot be predicted in any given case, will produce a relatively large number of acquittals when these matters go to trial.

One might think that this dynamic would encourage prosecutors to agree to plea bargains in assault cases. It could, but for the fact that the Federal

204. The high trial rates for 18 U.S.C. $\S \S 241$ and 242 crimes indicate that their high acquittal rates are not the product of selection bias, i.e., that only a very small subset of particularly weak cases are proceeding to trial. Compare the circumstances that surround charges of marijuana importation (21 U.S.C. § 952), discussed at the text accompanying notes $252-72$, infra.

205. Approximately 16 percent of all terminated 18 U.S.C. $\S 2241$ (a) counts within the database were resolved by way of trial. AOUSC Database, supra note 2.

206. Overall, of the 98,201 termination counts that alleged a $\S 1326$ charge, 88,370 related a conviction. This 90 percent conviction rate trails only 18 U.S.C. $§ 1028$ (a) and 18 U.S.C. $\S 4$ (both of which claimed a conviction rate of approximately 92 percent) among crimes with one thousand or more terminating counts within the AOUSC Database. AOUSC Database, supra note 2. 
Sentencing Guidelines for assault feature a sentencing "cliff." For a first offender, the Guidelines recommend a sentence of at least seventy months for assault with intent to murder; ${ }^{207}$ for aggravated assault, a minimum term of at least fifteen months is recommended. ${ }^{208}$ Enhancements for use of a weapon in connection with the offense and the infliction of bodily injury upon the victim can increase these figures substantially. ${ }^{209}$ The Guideline for simple assault, by contrast, advises a sentence of only zero to six months in custody. ${ }^{210}$ Moreover, an important symbolic difference exists between felony aggravated assault and misdemeanor simple assault; ${ }^{211}$ particularly when the victim suffered significant harm, prosecutors may balk at such a diminution of the charge. Given these considerations, a prosecutor in an aggravated assault case might regard a charge reduction to simple assault as giving up too much.

The high odds of acquittal and lack of attractive plea options lead to a forecast that a relatively high percentage of counts alleging aggravated assault will go to trial. And this turns out to be true; the federal data indicate that 9.7 percent of $\S 113(\mathrm{a})$ counts and 9.2 percent of $\S 113$ (c) counts go to trial, as compared to the overall trial rate of 4.4 percent of all counts within the AOUSC Database. $^{212}$

Even though the data presented above shed some light on trial and pleabargaining decisions, they leave some mysteries unresolved, such as why 18 U.S.C. $\S 924(j)$ has a very high trial rate even as it claims one of the lowest acquittal rates among federal offenses. The next Part thus relates a series of "case studies" that more carefully consider the plea-bargaining practices that surround individual crimes.

207. U.S. SENTENCING GUIDELINES MANUAL, supra note 5, § 2A2.1, Sentencing Table.

208. Id. § 2A2.2, Sentencing Table.

209. The Sentencing Guidelines call for a three-level increase in base offense level if a dangerous weapon is brandished, or its use threatened, in commission of the offense; a four-level increase if the dangerous weapon was actually used, short of discharge of a firearm; and a five-level increase if a firearm is discharged in connection with the offense. $I d$. § $2 \mathrm{~A} 2.2(\mathrm{~b})(2)$. Enhancements for injuries to the victim begin with a three-level increase for bodily injury and escalate to a seven-level increase for permanent or life-threatening bodily injury. Id. §2A2.2(b)(3). These weapon and injury enhancements, put together, cannot increase the base offense level by more than ten levels. Id.

210. 18 U.S.C. § 113(a)(4), (a)(5) (2006); U.S. SENTENCING GUIDELINES MANUAL, supra note $5, \S 2 \mathrm{~A} 2.3$, Sentencing Table.

211. Wright \& Engen, The Effects of Depth and Distance in a Criminal Code on Charging, Sentencing, and Prosecutor Power, supra note 19, at 1967 (noting the significance of the felony/misdemeanor distinction). Interestingly, Wright and Engen observe significant felony-tomisdemeanor charge movement among assault cases in their study of portions of the North Carolina code. Id. at 1960-61.

212. AOUSC Database, supra note 2. 
IV.

CASE STUdies

To better appreciate how the quirks of particular offenses can influence the resolution of criminal cases, this Part considers the plea and trial patterns that surround the crimes related at 18 U.S.C. $\$ 242$ (deprivation of civil rights under color of law); 8 U.S.C. $\S 1326$ (reentry of a deported alien); 18 U.S.C. $\S 924(\mathrm{j})$ (use of a firearm in the commission of a federal felony, in which death occurs); 18 U.S.C. $\S 952$ (importation of a narcotic or controlled substance; here, the case study focuses specifically on importation of marijuana); and 26 U.S.C. $§ 7201$ (tax evasion).

\section{A. 18 U.S.C. $\S 242$ (Deprivation of Civil Rights Under Color of Law)}

Section 242 charges implicate a combination of factors that push cases to trial. These charges are difficult to prove, they implicate a class of defendants with whom juries may sympathize, they are relatively rare, and they lack attractive plea-bargaining landing points. Furthermore, political and institutional pressures ensure that these charges will be filed in some situations where there exists a substantial chance of acquittal.

Section 242 is a civil rights crime. ${ }^{213}$ It provides that

$[\mathrm{w}]$ hoever, under color of any law, statute, ordinance, regulation, or custom, willfully subjects any person ... to the deprivation of any rights, privileges, or immunities secured or protected by the Constitution or laws of the United States, or to different punishments, pains, or penalties, on account of such person being an alien, or by reason of his color, or race, than are prescribed for the punishment of citizens

is guilty of a felony. ${ }^{214}$ Many $§ 242$ cases are brought against law enforcement officers. $^{215}$ The charges in these matters frequently allege that the defendant or defendants used excessive force. ${ }^{216}$

213. The story surrounding the enactment 18 U.S.C. $\S 242$ is described in Edward F. Malone, Legacy of the Reconstruction: The Vagueness of the Criminal Civil Rights Statutes, 38 UCLA L. REV. $163,171-79$ (1990). For a history of prosecutions under $\S 242$, see generally James P. Turner, Police Accountability in the Federal System, 30 MCGEORGE L. REV. 991 (1999).

214. 18 U.S.C. $\S 242(2006)$

215. Brian R. Johnson and Phillip B. Bridgmon, Depriving Civil Rights: An Exploration of 18 U.S.C. 242 Criminal Prosecutions 2001-2006, 34 CRIM. JUST. REV. 196, 198 (2009) ("Section 242 is aimed at public officers who abuse the constitutional or statutory rights of others."); Steven Puro, Federal Responsibility for Police Accountability Through Criminal Prosecution, 22 ST. LOUIS U. PUB. L. REV. 95, 106-11 (2003) (relating data on federal prosecutions under $\S 242$ from 1985 to 2001).

216. S. REP. No. 97-307, at 495 (1982); Reform of the Federal Criminal Laws: Hearing Before the Subcomm. on Criminal Laws and Procedures of the Comm. on the Judiciary, United States Senate, 93rd Cong. 6777 (1973) (statement of K. William O'Connor, Deputy Assistant Att'y Gen., Civil Rights Div., Dep't. of Justice) [hereinafter Reform of the Federal Criminal Laws-O'Connor Statement]. 
Proving these charges beyond a reasonable doubt can be difficult. ${ }^{217}$ Section 242 has been construed as requiring a specific intent to deprive an individual of his or her civil rights, as opposed to merely a general intent to commit an act that leads to injury. ${ }^{218}$ This element presents challenges for the prosecution, even in the best of cases. It can be difficult to communicate what this element actually means and how it applies to the proof adduced at trial. ${ }^{219}$ Furthermore, the evidence of intent in these cases can be ambiguous or susceptible to impeachment. ${ }^{220}$ In addition, to the extent that $\S 242$ cases typically involve police officers, juries have been known to nullify their instructions even when guilt has been established beyond a reasonable doubt. ${ }^{221}$ Here, the personalities of the defendants and victims likely play important roles in making jurors hesitant to convict. As the Civil Rights Division of the Department of Justice has explained, "[t]he victims of most official misconduct cases tend to be unsympathetic while the defendants often are well respected members of the community.",222

These circumstances collude to produce high acquittal rates at trial. The data in Part III show an acquittal rate of more than 50 percent for $\S 242$ counts tried within the FY2003-FY2009 case-termination period. ${ }^{223}$ This figure

217. See Seth Mydans, Tough Task Ahead in Beating Trial, N.Y. TIMES, Aug. 24, 1992, at A8 (describing official-misconduct civil-rights charges as difficult to prove). These problems are of longstanding vintage. See, e.g., 2 Ex-Cops Win Acquittal in Beating Trial, CHI. DAILY TRIB., Apr. 24, 1954, at 7 (relating the acquittal of two police officers in a federal civil-rights case).

218. Screws v. United States, 325 U.S. 91, 104 (1945); see also Michael J. Pastor, A Tragedy and a Crime?: Amadou Diallo, Specific Intent, and the Federal Prosecution of Civil Rights Violations, 6 N.Y.U. J. LEGIS. \& PUB. POL'Y 171, 176-84 (2002) (discussing the intent element and how lower courts have construed it).

219. Turner, supra note 213, at 1001 (observing that specific intent "has remained a troubling element of proof for prosecutors to meet" in these cases); see also John Frank, City Rarely Prosecutes Civil Rights Complaints, HOUS. CHRON., Dec. 1, 2004, at A1 ("Justice Department officials have said that civil rights cases against law enforcement officers are difficult to prosecute because of problems with the interpretation and perception of the law against civil rights abuses carried out 'under the color of law."').

220. See Reform of the Federal Criminal Laws-O'Connor Statement, supra note 216, at 6774 (opining that the jury instructions in $\S 242$ cases "which require the government to prove that the defendant acted with the specific intent to deprive the victim of a constitutional right" help explain the high acquittal rate in these matters); Puro, supra note 215, at 102 (observing that in $\S \S 241$ and 242 cases, "[m]ajor difficulties for prosecutorial success [include] standards of proof [and] juries' willingness to believe the police and the justification for their activities"); Mydans, supra note 217 (describing "[ $\mathrm{t}]$ he difficulty of proving criminal intent" as "one main reason" why official-misconduct civil rights cases are difficult to prove); see also Frank, supra note 219.

221. Turner, supra note 213, at 1109 (noting that "[j]ury nullification occurs in too many [§ 242] cases"').

222. Departments of Commerce, Justice, and State, the Judiciary, and Related Agencies Appropriations for 1998, Hearings Before a Subcomm. of the Comm. on Appropriations, House of Representatives, Part 2: Justification of the Budget Estimates, 105th Cong. 482 (1997).

223. Within the subset of cases in the AOUSC Database that involved at least one tried $\S 242$ count, if one removes these $\S 242$ charges from these cases, the acquittal rate at trial for the remaining charges drops to 40.3 percent. If one also removes counts under 18 U.S.C. $\S 241$ from these matters, the acquittal rate drops to 32.7 percent. AOUSC Database, supra note 2. 
comports with an earlier study of official-misconduct cases tried between 1985 and 2001, which found that "[o]nce the Criminal Section brought a [§ 242] law enforcement case to trial, there was substantial difficulty in obtaining a conviction." ${ }^{224}$ Specifically, over this span, "there were 254 convictions and 225 acquittals, an average of 15 convictions and 13 acquittals per year. ${ }^{, 225}$ If anything, these cases have been getting easier to prove; reports of prosecutions during the 1970s and 1960s reveal even higher acquittal rates. ${ }^{226}$

Once again, one might expect prosecutors to anticipate these impediments, and carefully screen these cases prior to filing. This expectation would be correct: statistics show a much lower filing rate for $\S 242$ cases referred for potential prosecution than for other types of offenses. ${ }^{227}$ Even with this rigorous screening, however, $\S 242$ cases produce high acquittal rates. The reasons are likely threefold: political and institutional pressures may lead prosecutors to file and try official-misconduct civil rights cases even when there exists a relatively high likelihood of acquittal; ${ }^{228}$ prosecutors may not fully account for juror reluctance to convict public officials of a crime; and once a $\S 242$ case is filed, there exist few attractive plea-bargaining options for the parties.

224. Puro, supra note 215 , at 113.

225. Id. Johnson and Bridgmon, supra note 215 , found that only 21 out of the $186 \S 242$ cases filed between 2001 and 2006 led to acquittals. Id. at 202. Though the author has neither confirmed nor refuted this finding, it is not necessarily inconsistent with Puro's observation of a high acquittal rate, or the gist of the data in the AOUSC Database. Even acknowledging the high trial rate associated with $\S 242$ charges, more of these cases produce guilty pleas than go to trial. Within the subset of cases that go to trial, a given case may involve an acquittal on one count and a conviction on another. Johnson and Bridgmon appear to count this result as a conviction, whereas the AOUSC Database records both the conviction counts and acquittal counts.

226. Reform of the Federal Criminal Laws-O'Connor Statement, supra note 216, at 6774 (observing that during fiscal year 1973, of the fifty-two police-officer defendants whose $\S 242$ cases involved the alleged use of excessive force, four had their cases dismissed at the government's motion, four pleaded guilty, forty-four were tried, and only nine of these forty-four were convicted-and noting this 25 percent overall conviction rate represented a significant increase from the conviction rate in similar cases in prior years); Reform of the Federal Criminal Laws: Hearing Before the Subcomm. on Criminal Laws and Procedures of the Comm. on the Judiciary, United States Senate, 93d Cong. 3160 (1972) (statement of Burke Marshall) (reporting that of the seventy-eight $\$ 242$ cases brought by the Department of Justice since January 1, 1970, sixty-seven had gone to trial, leading to convictions in only twelve of these cases, with only five convictions by jury). These acquittals were not just the products of jury nullification; in one high-profile $\S 242$ case - the prosecution of the National Guardsmen who shot antiwar protesters at Kent State University in 1970 - the trial court granted a defense motion to dismiss for insufficient evidence at the close of the prosecution's case. JAMES P. TURNER, THE OTHER SIDE OF THE MOUNTAIN: AN AUTOBIOGRAPHY 246-47 (2008).

227. Transactional Records Access Clearinghouse, Under Color of Law (Dec. 1, 2004), http://www.trac.syr.edu/tracreports/civright/107/.

228. See Frank, supra note 219 (observing that $\S 242$ cases are infrequent, high-profile matters). Well-publicized $\S 242$ cases in recent memory include the prosecutions of the Los Angeles Police Department officers who assaulted Rodney King, see United States v. Koon, 833 F. Supp. 769, 769 (C.D. Cal. 1995), and the prosecution of New York police officers who assaulted Abner Louima in 1997, see United States v. Schwarz, 259 F.3d 59, 59 (2d Cir. 2001). 
The last of these factors merits additional explanation. While other types of cases claim attractive plea-bargaining "landing points," there are few such alternatives with $\S 242$ charges. ${ }^{229}$ In $\S 242$ cases that involve excessive force, possible compromise offenses might include simple or aggravated assault. But federal courts lack jurisdiction over basic assault crimes except in rare cases, mostly involving admiralty or territorial jurisdiction (such as assaults that occur on military bases). In any event, from the prosecution's perspective, to compromise away the civil rights component of these cases would essentially abandon the federal interest in prosecution. Significant sentence bargains, in which the defendant receives a modest term of incarceration in exchange for a guilty plea, are almost as unlikely given the notoriety and political pressures that surround many $\S 242$ cases. Furthermore, if the defendant is a lawenforcement officer, a conviction for any felony crime (regardless of the sentence) can sound the death knell to his or her career (due to the general bar on the possession of a firearm by a felon), ${ }^{230}$ making such a deal relatively unpalatable from his or her standpoint. Given this dearth of mutually agreeable compromise options, many of these cases will proceed to trial.

\section{B. 8 U.S.C. $\$ 1326$ (Reentry of a Deported Alien)}

Unlike counts under 18 U.S.C. $\S 242$, charges brought under 8 U.S.C. $\S 1326$ (reentry by a deported alien) rarely go to trial. Moreover, as evidenced by the high integrity rate of $\S 1326$ charges, cases that allege this crime as the lead count infrequently result in charge bargains in which this count is replaced with a different, lesser charge. ${ }^{231}$ Instead, defendants tend to "plead to the sheet" in these matters.

229. Review of the most serious terminating charges in plea-bargained cases where the original "most serious" charge had been a $\S 242$ count illustrates the relative dearth of "landing points" for plea bargains in cases that allege these crimes. These 114 cases ultimately produced only 9 different most serious terminating offenses, even if one counts $\S 242$ twice (as both a felony and a misdemeanor); a felony $\S 242$ charge was the most serious terminating offense in 90 of these cases (or 78.9 percent). For purposes of comparison, 18 U.S.C. $\S 1519$ (obstruction of justice through the falsification, alteration, or destruction of records) was the most serious charging offense in 145 cases, yet these cases resulted in 31 different most serious terminating offenses, with the $\S 1519$ charge representing the most serious terminating offense in only 62 of these matters (or 42.8 percent). AOUSC Database, supra note 2.

230. Under federal law, it is unlawful for any person

who has been convicted in any court of, a crime punishable by imprisonment for a term exceeding one year ... to ship or transport in interstate or foreign commerce, or possess in or affecting commerce, any firearm or ammunition; or to receive any firearm or ammunition which has been shipped or transported in interstate or foreign commerce.

18 U.S.C. $\S 922(\mathrm{~g})(2006)$.

231. There exist few alternative charges that might provide the basis for such a bargain. Across the AOUSC Database, $\S 1326$ charges were rarely replaced as the most serious offense in a case that resolved by plea. Only two other crimes (8 U.S.C. $\S 1325$ (in 1014 cases) and 18 U.S.C. $\S 1001$ (in 108 cases)) supplanted $\S 1326$ as the lead charge in more than fifty pled-out cases over the studied time span, and overall, cases in which $\S 1326$ represented the most serious initial charge produced only twenty-two other most serious terminating charges (disregarding misdemeanor variations of felony 
The prevalence of pleas to $\S 1326$ counts, without any dismissal or reduction in charges, seems easy to explain. For starters, as discussed in Part $\mathrm{II}^{232}$ and confirmed by the data presented in Part III, ${ }^{233} \S 1326$ charges are simple to prove. As a result, virtually all defendants charged with this offense conclude that the two- or three-level reduction in base offense level they will receive for early acceptance of responsibility ${ }^{234}$ represents a far better outcome than the likely result they would obtain by taking their cases to trial. Or, better yet, a defendant may receive up to a four-level reduction pursuant to "fast track" early disposition proceedings, as are authorized in some districts where these cases are prevalent. ${ }^{235}$ Meanwhile, since $\S 1326$ charges involve a nonviolent, somewhat prosaic offense, prosecutors will accept docket-clearing compromises that provide defendants a modest sentencing break. Furthermore, $\S 1326$ charges are only rarely alleged together with additional crimes that may drag the $\S 1326$ count into trial. ${ }^{236}$ Finally, the substantial volume of $\S 1326$

offenses already accounted for) - a very low figure, in light of the enormous volume of $\S 1326$ cases. While an absence of "landing spots" normally discourages plea bargaining, the other circumstances that surround $\S 1326$ charges more than counterbalance any such tendency.

232. See supra text accompanying notes 72-77.

233. See supra text accompanying the tables at notes 165 and 185.

234. U.S. SENTENCING GUIDELINES MANUAL, supra note 5, § 3E1.1.

235. Id. $\S 5 \mathrm{~K} 3.1$ ("Upon motion of the Government, the court may depart downward not more than 4 levels pursuant to an early disposition program authorized by the Attorney General of the United States and the United States Attorney for the district in which the court resides."). "Fast-track programs allow a prosecutor to offer a defendant a reduced sentence in exchange for the defendant entering into a boilerplate plea agreement within a short period of time after indictment. These programs are typically used for immigration and drug-smuggling offenses." Evan W. Bolla, An Unwarranted Disparity: Granting Fast-Track Departures in Non-Fast-Track Districts, 28 CARDOZO L. REV. 895, 897 (2006). Only certain districts have received approval for fast-track proceedings, and these proceedings are limited to crimes that appear in such large volumes in those districts that the abbreviated proceedings will conserve significant resources. A list of the districts that offered "fast track" dispositions as of 2008, and the types of crimes eligible for these proceedings in these districts, can be found at Memorandum from Craig Morford, Acting Deputy Att'y Gen., to United States Att'ys for the following districts: Arizona, Central District of California, Eastern District of California, Northern District of California, Southern District of California, Middle District of Florida, Southern District of Florida, Northern District of Georgia, Idaho, Kansas, Nebraska, New Mexico, Eastern District of New York, North Dakota, Oregon, Puerto Rico, Southern District of Texas, Western District of Texas, Utah, Eastern District of Washington, and the Western District of Washington (Feb. 1, 2008), available at http:/www.fd.org/docs/select-topics---sentencing/u-s-department-of-justice-2-108-memo-regarding-reauthorization-of-early-disposition-programs-(fast-track).pdf?sfvrsn=4 [hereinafter Morford Memorandum]. Where fact-track proceedings are available, a large percentage of $\S 1326$ pleas tend to involve fast-track pleas. See, e.g., Government's Memorandum of Law in Opposition to the Defendant's Motion for a Non-guideline Sentence Based on the Existence of FastTrack Programs at 10; United States v. Krukowski, No. 04 Cr. 1308 (LAK) (June 10, 2005) (observing that in 2004, the Southern District of California processed $1878 \S 1326$ cases, with 1388 of these cases resolving through fast-track guilty pleas).

236. Within the aggregate dataset, almost 90 percent ( 89.3 percent) of all cases in which the initial charging document included a $\S 1326$ charge alleged only that one single count, and no others. For purposes of comparison, across the database as a whole, 52.1 percent of cases $(325,093 / 623,430)$ involved only a single initial charged count; 24.4 percent $(152,173 / 623,430)$ involved two charged 
cases leads to consistent plea expectations among both prosecutors and the defense. The result is a crime at the opposite end of the spectrum from the 18 U.S.C. $§ 242$ offense. ${ }^{237}$

The extremely low trial rates in $\S 1326$ cases raise another, more sensitive point. This Article is not about race, but issues of race and ethnicity are bound up with its claims that commoditized crimes are more subject to pleas than other offenses are, and that the identity of the defendants associated with a crime may affect the extent to which the offense becomes commoditized. Consistent with this argument, a crime that actively contributes to the commoditization of its defendants likely will lead to a relatively large number of pleas, and fewer trials. Section 1326 is such a crime. Due to language barriers or other limitations, the defendants charged with this offense often lack the ability to press for the tailored treatment of their cases. Even if they could, the simple construction of the $\S 1326$ crime does not accommodate individual narratives regarding a defendant's reasons for reentry. The character and constitution of 8 U.S.C. $\S 1326$ thereby ensures that a marginalized defendant class remains that way, and that the federal courtrooms are not swamped with trials involving this offense.

\section{18 U.S.C. $\$ 924(j)$ (Use of a Firearm in the Commission of a Federal Felony, Resulting in Death)}

It is easy to understand how the character and attendant circumstances of 18 U.S.C. $\S 242$ produce both acquittals and trials, while 8 U.S.C. $\S 1326$ has the opposite profile of low acquittal rates and few trials. The 18 U.S.C. $\S 924(j)$ data, by contrast, presents a bit of a mystery.

Within the dataset, this crime was dismissed pursuant to plea deals more often than almost any other federal felony. ${ }^{238}$ At the same time, this charge was also taken to trial relatively often-where it almost invariably led to a conviction. $^{239}$ These figures present at least two questions: Why were prosecutors so willing to dismiss these charges? And why did a relatively large number of these cases go to trial, given the low odds of acquittal?

The answer to these questions begins with the language of $\S 924(j)$, which provides:

counts; 9.7 percent $(60,227 / 623,430)$ involved three charged counts; 5.6 percent $(35,136 / 623,430)$ involved four charged counts; and 8.1 percent $(50,801 / 623,430)$ involved five or more charged counts.

237. The fact that almost 90 percent of all $\S 1326$ counts during the studied time period ultimately resulted in convictions also underscores the nature of this crime as an almost foolproof allegation for the prosecution. Only two frequently alleged crimes had higher overall conviction rates, on a count-specific basis: 18 U.S.C. $\S 1028$ (a) and 18 U.S.C. $\S 4$. AOUSC Database, supra note 2.

238. See supra text accompanying note 156 .

239. See supra Table VI. High dismissal rates are not entirely inconsistent with high trial rates, given how few federal criminal cases actually go to trial. As related earlier in this Article, over the studied time period, no commonly charged crime saw trials on more than 30.1 percent of alleged counts. 
[A] person who, in the course of a violation of subsection (c) [use of a firearm in the commission of a federal drug crime or violent felony], causes the death of a person through the use of a firearm, shall-(1) if the killing is a murder (as defined in section 1111) be punished by death or by imprisonment for any term of years or for life; and (2) if the killing is manslaughter (as defined in section 1112), be punished as provided in that section. ${ }^{240}$

Thus,

[t]here are four elements that the Government must prove in order to sustain a violation of $\S 924(\mathrm{j}): 1$ ) the commission of a federal crime of violence or drug trafficking; 2 ) the use or carrying of a firearm during or in furtherance of such a crime; 3 ) the death of person by the use of the firearm; and 4) the death was caused by murder [or manslaughter] as defined in 18 U.S.C. $\S 1111$ [or $\S 1112$ ]. ${ }^{241}$

Significantly, most courts hold that the punishment prescribed by $\S 924(\mathrm{j})$ is cumulative to any sentence imposed for the predicate felony or felonies. ${ }^{242}$

The composition of this crime and its relationship to other offenses go a long way toward explaining why $\S 924(\mathrm{j})$ charges were frequently dismissed pursuant to plea bargains. Like several other "charging crimes," §924(j) presumes the existence of another serious felony charge, which is customarily alleged alongside the $\S 924(\mathrm{j})$ count and may serve as the basis for a bargain. There are many such related offenses-from racketeering crimes to drug offenses to the use of violence against a prospective witness-and these crimes create an array of possible "landing points" for plea deals. In all, cases terminating in a plea in which a count under 18 U.S.C. § 924(j) represented the most serious initial charge ultimately led to thirty-one different most serious terminating charges. ${ }^{243}$

At the same time, the gravamen and consequences of a $\S 924(\mathrm{j})$ charge, and the environments in which it operates, encourage trials in cases where the defendant was intimately involved in a homicide-a scenario that ups the stakes for the prosecution and the defense. For the prosecution, in a substantial share of these cases, the $\S 924(\mathrm{j})$ count is the closest thing to a murder charge that the federal government can allege, since there is no general federal jurisdiction for murder. And as previously discussed, ${ }^{244}$ prosecutors are reluctant (relatively speaking) to dismiss or reduce murder charges. Also, $\S 924(\mathrm{j})$ cases tend to require significant investments of time and effort by the prosecution; this commitment of resources, together with the notoriety that

240. 18 U.S.C. $§ 924(j)(2006)$.

241. United States v. Winston, 55 F. App'x 289, 300 (6th Cir. 2003).

242. E.g., United States v. Battle, 289 F.3d 661 (10th Cir. 2002). Compare United States v. Julian, 633 F.3d 1250 (11th Cir. 2011), which held that it lies within a district court's discretion to impose a concurrent sentence for an 18 U.S.C. § 924(j) conviction.

243. AOUSC Database, supra note 2.

244. See supra text accompanying note 108. 
often attaches to these proceedings, can make prosecutors less interested in plea concessions. $^{245}$

Other recurring attributes of $\S 924(j)$ cases may encourage defendants in these matters to demand trials. As previously mentioned, a trial on the $\S 924(\mathrm{j})$ count is a given if prosecutors refuse to take the death penalty off the table. ${ }^{246}$ In other cases, the presence of several overlapping charges, as tend to appear in these matters, can mean that a defendant faces so much potential custody time with or without a plea deal to the $\S 924(\mathrm{j})$ count that she will opt to roll the dice at trial. ${ }^{247} \mathrm{~A}$ defendant, looking forward from the time of plea negotiations, may not glean substantial value from a thirty-year rather than forty-year sentence; either way, freedom lies decades down the road. ${ }^{248}$ Perhaps equally important, these charges often appear in connection with gang or organized crime activity, as to which special deterrents may exist to the entry of a guilty plea. In such cases, defendants might be concerned that their confederates will consider such a plea as a betrayal and seek revenge.

The data underscore the high stakes that many of these cases involve. In 181 of the 367 cases in the AOUSC Database that included a $\S$ 924(j) charge, the defendant ultimately received a prison sentence of at least thirty years. In the subset of $\S 924(\mathrm{j})$ cases that went to trial and produced a guilty verdict on at least one count, 90 percent (111 out of 124) led to prison sentences of at least thirty years. ${ }^{249}$ More tellingly, across tried cases involving a count under $\S 924(\mathrm{j})$, there was an acquittal rate for all crimes of only 5 percent. ${ }^{250}$ All in all, it appears that when this crime goes to trial, the stakes may be so high for

245. See Margareth Etienne \& Jennifer K. Robbennolt, Apologies and Plea Bargaining, 91 MARQ. L. REV. 295, 319 (2007) (observing that " $[\mathrm{t}]$ he psychological effects of . . . sunk costs, which make it difficult for civil claimants to abandon their efforts, may make it difficult for victims and prosecutors to do so as well").

246. While there normally exists no outright bar to such a plea, see Anthony J. Casey, Maintaining the Integrity of Death: An Argument for Restricting a Defendant's Right to Volunteer for Execution at Certain Stages of Capital Proceedings, 30 AM. J. CRIM. L. 75, 92-93 (2002) (noting that only Arkansas and New York have outright bans on guilty pleas to a capital crime, as to which the death penalty may represent a consequence of the plea), "a case in which a death sentence was imposed is virtually certain to have gone to trial - not many lawyers are reckless enough to advise clients to plead guilty to capital murder without an agreement or understanding that doing so will avoid the death penalty." James S. Liebman, The Overproduction of Death, 100 COLUM. L. REV. 2030, 2108 (2000).

247. Cases in which $\S 924(\mathrm{j})$ charges appear typically involve numerous other charges, in addition to the $\S 924(\mathrm{j})$ count. The dataset identifies initial charging documents as alleging a $\S 924(\mathrm{j})$ count in 345 cases (this likely undercounts the total number of cases that commenced with a § 924(j) count, since they may have represented the sixth, seventh, or higher count in some cases). Of these matters, 263, or 76.2 percent, involved at least five charged counts. AOUSC Database, supra note 2.

248. See Easterbrook, supra note 24, at 295, 312-16 (discussing how defendants discount future incarceration, relative to imminent custody).

249. AOUSC Database, supra note 2.

250. Id. 
the defendant, ${ }^{251}$ and the prosecution so reluctant to offer significant concessions, that trial represents the defense's only real strategic optionnotwithstanding the low odds of acquittal.

\section{21 U.S.C. $\S 952$ (Importation of Marijuana)}

Another mystery presented by the data concerns the relative rarity of tried 21 U.S.C. $\S 952$ counts that alleged the importation of marijuana, as juxtaposed against the relatively high acquittal rate in these matters. ${ }^{252}$ Just 1.2 percent of 21 U.S.C. $§ 952$ counts that alleged marijuana importation went to trial. ${ }^{253}$ These counts yielded an acquittal rate of 37.6 percent (with 118 out of 189 tried counts leading to convictions), almost twice the database average across all counts. ${ }^{254}$ Particularly given the mandatory minimum sentences that adhere to federal drug crimes-which suggest that the high plea rate results from something other than extremely generous sentence offers by prosecutors-this disconnect poses the question of whether the high acquittal rate resulted from a particularly potent selection-bias effect, whereby only especially weak $\S 952$ marijuana cases go to trial.

The data suggest an affirmative response to this question. First, the data reveal that these cases tended not to involve much "charge stacking" by the prosecution. Between FY2003 and FY2009, 15,351 cases alleged at least one marijuana-importation count under 21 U.S.C. $\S 952$ at the time of initial filing. ${ }^{255}$ Seventy-nine percent of these cases were simple one- or two-count matters. ${ }^{256}$ In $\S 952$ cases that alleged only one other count, more than 90 percent of the time, the second count alleged possession of marijuana with an intent to sell or distribute (21 U.S.C. $\S 841$ ) or conspiracy to distribute marijuana (21 U.S.C. $§ 846$ )-logical charges to join with an importation count, at least when more than a small amount of marijuana is involved. When these matters are resolved by plea, one or another of these two charges is commonly dismissed; ${ }^{257}$ and in any event, the two charges may represent

251. Elder, supra note 33, at 199 (finding, per a regression analysis, that factors that "increase[e] the stakes" of a case, such as the use of a weapon in the commission of a crime, or harm or death to the victim, reduce the likelihood of a plea bargain).

252. The AOUSC Database divides marijuana-importation counts among three codes (21:952=MI.F; 21:952A=MI.F; and 21:952B=MI.F). One of these codes (21:952B=MI.F) accounted for very few charges; the other two exhibited very similar patterns.

253. AOUSC Database, supra note 2.

254. Id.

255. Id.

256. Id. Across the seven-year period studied, $4115 \S 952$ marijuana cases ( 27 percent) alleged only a single count; 7993 (52 percent) alleged two counts; 685 (4 percent) alleged three counts; 2146 (14 percent) alleged four counts; and 412 (3 percent) alleged five or more counts. AOUSC Database, supra note 2.

257. Id. (reflecting dismissals as to the second count in more than 80 percent of terminated two-count 21 U.S.C. $§ 952$ marijuana-importation proceedings). 
"closely related counts" under the Federal Sentencing Guidelines, such that the second charge does not threaten significant additional punishment. ${ }^{258}$

Second, most of these cases were simple to prove, and there existed powerful inducements for a resolution by way of a guilty plea. ${ }^{259}$ Of the 15,383 cases in which a $\S 952$ marijuana-importation charge appeared at the time of case termination, only 5.7 percent did not result in a conviction. ${ }^{260}$ By way of comparison, across the AOUSC database as a whole, only 89.5 percent of cases resulted in convictions. ${ }^{261}$ Furthermore, due to their concentration within a few judicial districts (discussed below), these cases tended to be eligible for "fast track" proceedings, which encourage early defense pleas by offering defendants up to a four-level base offense level reduction. ${ }^{262}$ The availability of this downward departure for early pleas contributed to a substantial sentencing differential between plea-bargained dispositions and dispositions by trial. The median prison term issued in $\S 952$ marijuana-importation matters that resolved by plea was only fifteen months. ${ }^{263}$ In tried cases, this figure spiked to thirtythree months. ${ }^{264}$

Third, and finally, § 952 cases are concentrated within a few jurisdictions. Between them, the Western District of Texas and the Southern District of California accounted for more than 85 percent $(13,105 / 15,383)$ of all terminated $\S 952$ matters within the aggregate dataset. ${ }^{265}$ Four districts-the two just mentioned, together with the Southern District of Texas and the District of Arizona-accounted for more than 95 percent $(14,664 / 15,383)$ of these cases. ${ }^{266}$

These conditions - simple cases, recurring charges, low stakes but a trial penalty for the defense, and concentration of many cases within a few

258. See U.S. SENTENCING GUIDELINES MANUAL, supra note 5, §§ 3D1.1, 3D1.2 (discussing the "grouping" of, inter alia, certain factually related drug crimes for purposes of determining the applicable sentence).

259. But cf. Hubachek Testimony, supra note 74, at 6 (discussing triable issues regarding the defendant's knowledge, or lack thereof, that sometimes appear in $\S 952$ cases, and describing the knowledge element as "often difficult to demonstrate").

260. AOUSC Database, supra note 2.

261. Id.

262. Morford Memorandum, supra note 235 (reauthorizing "fast track" proceedings for drugimportation cases arising in the Southern District of California, the Western District of Texas, the District of Arizona, and the Laredo division of the Southern District of Texas); see also Hubachek Testimony, supra note 74 (discussing the use of fast-track proceedings within the Southern District of California in cases brought under 21 U.S.C. § 952).

263. AOUSC Database, supra note 2.

264. Because the penalties in these cases are tied to the amount of drugs involved, one can hypothesize that most importation cases involve moderate quantities of the drug. The Sentencing Guidelines prescribe a thirty-three-month term for possession of at least forty, but less than sixty kilograms of marijuana. U.S. SENTENCING GUIDELINES MANUAL, supra note 5, § 2D1.1, Sentencing Table.

265. AOUSC Database, supra note 2.

266. Id. 
jurisdictions-suggest that there will be a high percentage of pleas in $\S 952$ cases, and attorneys who are well positioned to spot the handful of cases in which a defense may be viable. ${ }^{267}$ And if one looks at the trial data, it becomes apparent that the $\S 952$ charges that did go to trial arose in a handful of relatively weak cases. The acquittal rate for marijuana-importation charges under 21 U.S.C. $\S 952$ was, as stated previously, 37.6 percent. ${ }^{268}$ Tellingly, the acquittal rate for all other charges in these cases was not far behind, at 37.4 percent. ${ }^{269}$ Crimes that normally yielded convictions at trial suddenly became acquittal-prone within this narrow universe of tried cases. For example, the overall acquittal rate at trial for charges under 21 U.S.C. $§ 841(a)$, alleging possession of marijuana for sale or distribution, was 24.8 percent. ${ }^{270}$ In tried cases that alleged a $\S 952$ count, this figure soared to 34.6 percent. $^{271}$

The foregoing analysis suggests that the rarity of trials and high acquittal rates for $\S 952$ marijuana charges likely resulted from sophisticated case evaluation by defense attorneys. In the handful of jurisdictions that entertain a large number of $\S 952$ cases, attorneys see enough of these matters to develop a sense as to which cases are worth taking to trial. Not many are. Yet a select few do pass this test. With this limited universe of cases, many likely involve disputes over the defendant's intent to import the marijuana. ${ }^{272}$ Under the circumstances, the defendant is either guilty of importation and possession with the intent to sell or distribute, or guilty of no crime at all. The prosecution subscribes to the former point of view, the defense the latter. Few possible charge bargains exist in these cases, and barring a sentence bargain (which may be difficult, given mandatory minimum sentences) these matters will proceed to trial, even where there is a high likelihood of acquittal.

267. Most likely, these defenses involve an allegedly insufficient connection between the defendant and the marijuana. "In order to obtain a conviction for importation of marijuana under 21 U.S.C. $\S \S 952$ and 960 , the government must prove that the defendant (1) intentionally brought the marijuana into the United States; and (2) knew that it was a controlled substance." United States v. Moytez-Pineda, 312 F. App'x 859, 861 (9th Cir. 2009). When importation in a vehicle is involved, "a passenger [in a vehicle containing contraband] may not be convicted [of drug offenses] unless there is evidence connecting him with the contraband, other than his presence in the vehicle." Id. Specifically, "[t]he government must show that the defendant has knowledge of the presence of the drugs and 'the power to exercise dominion and control over it."' $I$ d. at 861-62.

268. AOUSC Database, supra note 2.

269. Id.

270. Id.

271. Id.

272. E.g., United States v. Ramirez, 176 F.3d 1179, 1181 (9th Cir. 1999) (observing that "mere knowledge of the presence of contraband, without evidence suggesting a passenger's dominion or control of the contraband, is insufficient to prove possession," and reversing a defendant's conviction of importation of marijuana on insufficient-evidence grounds). 


\section{E. 26 U.S.C. $\$ 7201$ (Tax Evasion)}

Finally, some offenses ensnare a relatively high percentage of defendants who will refuse to enter a plea under almost any circumstances, no matter how generous the proffered terms. Some of these defendants might insist on objectively hopeless trials for a reason that oversimplified, punishment-focused applications of the rational-actor model do not fully account for: principle.

In particular, the plea and trial rates for tax crimes suggest that some defendants in these cases are true believers who will refuse to accept plea bargains that a "rational" defendant would eagerly embrace. ${ }^{273}$ As mentioned at the outset of this Article, charges of felony tax evasion (26 U.S.C. $§ 7201)$ went to trial approximately three times as often as the dataset average (12.2 percent of these counts were tried, as compared to 4.4 percent for the database as a whole), ${ }^{274}$ even as the acquittal rate for these charges (13.8 percent) was significantly lower than the average for all crimes. ${ }^{275}$ Unlike charges under 18 U.S.C. $\S 924(j)$, this disparity cannot be explained by reference to any particularly severe consequences of conviction; sentences for tax evasion are rarely more than a few years, unless the defendant is a repeat offender or the evaded taxes are massive. ${ }^{276}$

Some defendants refuse to enter guilty pleas in these cases because of the costs of conviction, others because of the benefits they believe will accrue only from taking a case to trial. Well-heeled tax-evasion defendants within the former category may opt against trial because the stigma that attaches to any conviction-by plea or by trial-represents a large component of the

273. The Internal Revenue Service has dedicated a publication to debunking "frivolous" tax arguments. IRS, The Truth About Frivolous Tax Arguments (Feb. 16, 2012), http://www.irs.gov/pub/irs-utl/friv_tax.pdf; see also U.S. DEP'T OF JUSTICE, Nathan J. Hochman, Tax Division's Assistant Attorney General, Announces the Creation of the National Tax Defier Initiative (Apr. 8, 2008), http://www.justice.gov/opa/pr/2008/April/08-tax-275.html (announcing stepped-up enforcement of the tax laws as against "tax defiers," defined as "someone who rejects the legal foundation of the tax system, despite decades of legal precedent upholding the system's constitutional and statutory validity, and who takes specific and concrete action to violate the law").

274. AOUSC Database, supra note 2.

275. Id. Likewise, the tax crimes related at 26 U.S.C. $\S 7202$ and $\S 7203$ (the latter as a misdemeanor and as a felony) exhibited lower acquittal rates (7.4, 8.5, and 4.4 percent, respectively), than the overall database average, but higher trial rates $(8.9,6.0$, and 16.6 percent) than the database as a whole. AOUSC Database, supra note 2. As to one of these offenses (26 U.S.C. $\$ 7203$, charged as a felony, which reflects the willful failure to file the proper IRS form upon receipt of $\$ 10,000$ or more in cash as part of a business transaction) this pattern likely owed in part to its use as a money-laundering count in complex, high-stakes criminal prosecutions that are prone to trials. See Bickham LincolnMercury Inc. v. United States, 168 F.3d 790, 793 (5th Cir. 1999) (describing the nature of reporting requirement implicated by $\S 7203$ 's felony provision). Somewhat like 18 U.S.C. $\S 924(\mathrm{j})$, this crime finds itself being dragged to trial by other crimes charged alongside it.

276. The Federal Sentencing Guidelines tether the custodial terms for tax evasion to the amount of tax that was evaded. U.S. SENTENCING GUIDELINES MANUAL, supra note 5, § 2T4.1. A tax loss of $\$ 100,000$, assuming a first offender with no aggravating circumstances, leads to a Guidelines range of 21-27 months in custody; a tax loss of $\$ 1,000,000$, with the same assumptions, leads to a Guidelines range of 41-51 months in custody. Id., Sentencing Table. 
punishment that attaches to the offense. ${ }^{277}$ Tax-evasion defendants in the latter class, meanwhile, may refuse a guilty plea because they sincerely believe that the federal tax laws are unconstitutional.

These constitutional challenges do not work out well for defendants. Almost twenty years ago, the United States Supreme Court held that a considered, fundamental disagreement with the constitutionality of the tax laws does not represent a valid defense to a charge of tax evasion. ${ }^{278}$ Yet even with this guidance, many tax resisters remain unwilling to concede the point, and demand to take their cases to trial. ${ }^{279}$ One exasperated federal judge catalogued some of the "tired arguments"

That the Sixteenth Amendment to the U.S. Constitution was improperly ratified and therefore never came into being; That wages are not income and therefore are not subject to federal income tax laws; That tax laws are unconstitutional; That filing a tax return violates the privilege against self incrimination under the Fifth Amendment to the U.S. Constitution; That Federal Reserve Notes do not constitute cash or income. ${ }^{281}$

That defendants continue to press these arguments in court despite their nonexistent odds of success underscores how many parties simply do not behave as extrapolation from likely trial outcomes might predict. To these defendants, principle or other inchoate interests override tangible matters like custody time, upon which most rational defendants are supposed to fixate. ${ }^{282}$ This point is often lost, however, even on the most astute observers. The passage in the paragraph above, for example, which relates a series of predictably futile arguments that defendants may prefer over plea deals, was written by none other than Judge Frank Easterbrook. ${ }^{283}$

277. Celebrities charged with tax evasion over the past few years include Formula One racecar driver Helio Castroneves, see Indictment, United States v. Castroneves, No. 08-20916 (S.D. Fla. Oct. 2, 2008); and movie actor Wesley Snipes, see Indictment, United States v. Kahn, No. 5:06-cr-22Oc-10GRJ (M.D. Fla. Apr. 5, 2006).

278. Cheek v. United States, 498 U.S. 192, 204-06 (1991) (rejecting a defendant's claim that a studied objection to the constitutionality of the federal tax laws represents a defense to tax evasion).

279. See Russell v. United States, 339 F. App’x 637, 638 (7th Cir. 2009) (citing many judicial opinions, including several in criminal cases, that rejected constitutional attacks on the tax laws); United States v. Matthies, 319 F. App’x 554, 557 (9th Cir. 2009) (approving of the district court's limitation on defendants' proffered trial testimony regarding the constitutionality of the tax laws); United States v. Swan, 198 F. App'x 21, 22 (1st Cir. 2006) (observing that the defendant, convicted after a jury trial, raised an argument concerning the constitutionality of the tax laws that was precluded by United States Supreme Court precedent).

280. United States v. Buckner, 830 F.2d 102, 103 (7th Cir. 1987) (quoting Coleman v. Comm'r, 791 F.2d 68, 70 (7th Cir. 1986)).

281. Id.

282. See Stuntz, supra note 15 , at 2554 (observing that in criminal cases, "the defendant almost always prefers freedom to incarceration and less incarceration to more").

283. Buckner, 830 F.2d at 104. 


\section{CONCLUSION}

The preceding discussion establishes that crime content and the relationships among criminal offenses can have significant effects upon pleabargaining practices. This awareness offers a better understanding of the factors that encourage and stymie plea bargains, and sheds additional light on the limitations and nuances of the rational-actor model.

The connections that exist between charge substance and plea bargaining also hint at two other broader subjects for consideration. First, these relationships underscore how conventions and expectations that seem to have little to do with plea bargaining can exert a subtle but powerful effect on individual case outcomes. Legislatures influence plea bargaining through the superstructure of crimes and sentencing rules that they devise. Less obviously, through our values, beliefs, and priorities, the general public contributes to the commoditization of certain crimes and defendants-while expecting customized justice for individuals charged with other offenses. Prosecutors, defense attorneys, defendants, and judges do not operate in a complete vacuum when they broker and approve plea bargains. Society sends these actors cues, mostly faint but occasionally forceful, which help them understand both what is acceptable and what is possible within the courtroom. To the extent that we harbor concerns regarding modern plea bargaining, these problems are ultimately our problems, and any solutions will require more than simple venting at courtroom practices.

Second, data similar to that related in this Article could and should produce more thoughtful evaluations of new and existing crimes. ${ }^{284}$ Today, the debates over most new crimes could charitably be described as banal. And once a crime has been enacted, there exists little to no ongoing consideration of how the offense is being utilized. As this Article demonstrates, there already exists useful information regarding the invocation and application of specific crimes. One can discern with relative ease how often prosecutors charge a crime; the circumstances in which it has been charged; the plea bargains the crime has produced, and the sentences associated with those deals; the frequency with which a charge goes to trial; and the outcomes in these trials. In other words, one can tell how-and how well-a crime is working.

This information, appropriately harnessed, would facilitate and enhance the evaluation of new and existing crimes. For starters, the utilization of comparable offenses could help legislatures predict how a proposed crime will be deployed. On this point, consider a different market analogy. When a business considers whether to launch a new product line, it often will research

284. In The Effects of Depth and Distance in a Criminal Code on Charging, Sentencing, and Prosecutor Power, supra note 19, Wright and Engen suggest another use for charge-level plea data: guides based on plea data that prosecutors and defense attorneys could use to gauge what a fair, or at least, conventional plea deal would entail. Id. at 1977-78. 
how similar products have fared in the past. The business also will consider the costs and benefits associated with production, including how much the product will cost to produce and what return it will provide on invested capital. These steps are so common, and so taken for granted, that one would regard a business that failed to engage in this sort of benchmarking as likely headed for insolvency.

Legislative consideration of new crimes should be no different. Patterns of use for comparable existing crimes can help legislatures anticipate how proposed new offenses will be utilized, with these predictions permitting the improved appraisal of the costs and benefits associated with the suggested addition to the criminal code. This proposal is not wholly hypothetical. In 2011, Colorado enacted a law $^{285}$ that requires the preenactment screening of new crimes. Under this statute, these crimes are to be accompanied by a fiscal note that includes, among other information, (a) an analysis of whether the new crime can already be charged under current law; (b) a comparison of the proposed crime to similar offenses; and (c) "an analysis of the current and anticipated future prevalence of the behavior that the proposed new crime . . . intends to address." 286 Though this measure stops short of calling for the comprehensive analysis of the usage of offenses similar to the new crime, it represents a step in this direction.

Furthermore, we know very little about the utilization of existing crimes-from 2 U.S.C. $§ 192$ (congressional contempt) ${ }^{287}$ to 50A U.S.C. $\S 2410$ (b) (willful violation of war-material export regulations). ${ }^{288}$ As matters stand, we lack answers to some very basic questions regarding specific federal criminal laws, such as: Which of the estimated 4450 federal crimes are

285. COLO. ReV. STAT. ANN. § 2-2-322 (West 2011).

286. Id.

287. Every person who having been summoned as a witness by the authority of either House of Congress to give testimony or to produce papers upon any matter under inquiry before either House, or any joint committee established by a joint or concurrent resolution of the two Houses of Congress, or any committee of either House of Congress, willfully makes default, or who, having appeared, refuses to answer any question pertinent to the question under inquiry, shall be deemed guilty of a misdemeanor, punishable by a fine of not more than $\$ 1,000$ nor less than $\$ 100$ and imprisonment in a common jail for not less than one month nor more than twelve months.

2 U.S.C. $\$ 192(2006)$.

288. Pursuant to 50A U.S.C. $\$ 2410$ (b):

Whoever willfully violates or conspires to or attempts to violate any provision of this Act [sections 2401 to 2420 of the Appendix to Title 50 of the United States Code, which deal with export controls] or any regulation, order, or license issued thereunder, with knowledge that the exports involved will be used for the benefit of, or that the destination or intended destination of the goods or technology involved is, any controlled country or any country to which exports are controlled for foreign policy purposes - (A) except in the case of an individual, shall be fined not more than five times the value of the exports involved or $\$ 1,000,000$, whichever is greater; and (B) in the case of an individual, shall be fined not more than $\$ 250,000$, or imprisoned not more than 10 years, or both.

50A U.S.C. $§ 2410(b)(2006)$. 
actually utilized, and which are effectively moribund? Which crimes have the highest and lowest conviction rates? Which crimes tend to be most difficult to prove, when put in front of judges and juries? What other trends or patterns, if any, emerge when one examines the invocation of particular crimes across judicial districts, and over time?

The answers to these questions matter, both to policy makers and practitioners. Today, assertions that the federal code contains "too many" crimes, ${ }^{289}$ that prosecutors are coercing plea bargains through improper or overzealous charging practices, ${ }^{290}$ and that other aspects of "overcriminalization" are undermining the rule of law ${ }^{291}$ tend to rely on anecdotal evidence more than hard data regarding the utilization of particular offenses. It is therefore unsurprising that these assertions have failed to produce significant substantive reforms; even if legislators were inclined to revisit the criminal laws, they rarely would know precisely which crimes merit their attention. If, on the other hand, it was generally understood precisely which crimes lie fallow, which crimes seem to be used to coerce plea bargains, and which crimes are most difficult to prove, reformers would have a better sense as to where to target their energies.

In the final analysis, this Article argues that in at least one important way, crimes should be treated more like widgets, or at least more like "normal" products. Just as corporations engage in market studies prior to a product launch, they also will periodically assess whether their existing products have generated substantial profits, or are leading to losses. Congress and state legislatures have manufactured thousands of crimes. It is difficult to believe that all of these crimes have produced the "profits"-social gains-that legislators believed they would. Close review of crime-specific data would allow states and the federal government to shut down poor-performing product lines, streamline others, and perhaps even add a few new models. Crimes may

289. "The academic consensus is that federal criminal law . . . includes too many offenses ... and covers too many people within the scope of its sanctions. The criminal law of the states has also been charged with being bloated and rapacious, although there the consensus may be weaker." Samuel W. Buell, The Upside of Overbreadth, 83 N.Y.U. L. REV. 1491, 1497-98 (2008) (footnote omitted).

290. Here, a distinction must be drawn between those commentators who allege that prosecutors frequently allege offenses that cannot be proved beyond a reasonable doubt, e.g., ANGELA J. DAVIS, ARBITRARY JusticE: THE POWER OF THE AMERICAN PROSECUtOR 31 (2007) ("Prosecutors routinely engage in overcharging, a practice that involves 'tacking on' additional charges that they know they cannot prove beyond a reasonable doubt or that they can technically prove but are inconsistent with legislative intent or otherwise inappropriate."), and those who claim that prosecutors often bring charges that, although supported by adequate facts, seem too severe in light of the surrounding circumstances, e.g., Norman Abrams, The New Ancillary Offenses, 1 CRIM. L.F. 1, 25 (1989).

291. See generally DOUGLAS HuSAK, OVERCRIMINALIZATION: THE Limits OF THE CRIMINAL LAW (2008). 
[Vol. 100:1573

not represent widgets, but that does not mean we cannot take an inventory of our previous orders. 